\title{
Review \\ Fertility-Sparing Surgery for Ovarian Cancer
}

\author{
Geoffroy Canlorbe ${ }^{1,2,3, *}$, Nathalie Chabbert-Buffet ${ }^{2,3,4}$ and Catherine Uzan 1,2,3
}

1 Department of Gynecological and Breast Surgery and Oncology, Pitié-Salpêtrière, Assistance Publique des Hôpitaux de Paris (AP-HP), University Hospital, 75013 Paris, France; catherine.uzan@aphp.fr

2 Centre de Recherche Saint-Antoine (CRSA), INSERM UMR_S_938, Cancer Biology and Therapeutics, Sorbonne University, 75012 Paris, France; nathalie.chabbert-buffet@aphp.fr

3 University Institute of Cancer, Sorbonne University, 75013 Paris, France

4 Department of Gynaecology, Obstetrics and Reproductive Medicine, Tenon University Hospital, Assistance Publique des Hôpitaux de Paris (AP-HP), Sorbonne University, 75020 Paris, France

* Correspondence: Geoffroy.canlorbe@aphp.fr

Citation: Canlorbe, G.;

Chabbert-Buffet, N.; Uzan, C. Fertility-Sparing Surgery for Ovarian Cancer. J. Clin. Med. 2021, 10, 4235. https://doi.org/10.3390/jcm10184235

Academic Editors: Jacques Donnez and Marie-Madeleine Dolmans

Received: 18 August 2021

Accepted: 15 September 2021

Published: 18 September 2021

Publisher's Note: MDPI stays neutral with regard to jurisdictional claims in published maps and institutional affiliations.

Copyright: (c) 2021 by the authors. Licensee MDPI, Basel, Switzerland. This article is an open access article distributed under the terms and conditions of the Creative Commons Attribution (CC BY) license (https:// creativecommons.org/licenses/by/ $4.0 /)$.

\begin{abstract}
Background: although most patients with epithelial ovarian cancer (EOC) undergo radical surgery, patients with early-stage disease, borderline ovarian tumor (BOT) or a non-epithelial tumor could be offered fertility-sparing surgery (FSS) depending on histologic subtypes and prognostic factors. (2) Methods: we conducted a systematic review to assess the safety and fertility outcomes of FSS in the treatment of ovarian cancer. We queried the MEDLINE, PubMed, Cochrane Library, and Cochrane ("Cochrane Reviews") databases for articles published in English or French between 1985 and 15 January 2021. (3) Results: for patients with BOT, FSS should be offered to young women with a desire to conceive, even if peritoneal implants are discovered at the time of initial surgery. Women with mucinous BOT should undergo initial unilateral salpingo-oophorectomy, whereas cystectomy is an acceptable option for women with serous BOT. Assisted reproductive technology (ART) can be initiated in patients with stage I BOT if infertility persists after surgery. For patients with EOC, FSS should only be considered after staging for women with stage IA grade 1 (and probably 2, or low-grade in the current classification) serous, mucinous or endometrioid tumors. FSS could also be offered to patients with stage IC grade 1 (or low-grade) disease. For women with serous, mucinous or endometrioid high-grade stage IA or low-grade stage IC1 or IC2 EOC, bilateral salpingo-oophorectomy and uterine conservation could be offered to allow pregnancy by egg donation. Finally, FSS has a large role to play in patients with non- epithelial ovarian cancer, and particularly women with malignant ovarian germ cell tumors.
\end{abstract}

Keywords: ovarian cancer; fertility sparing surgery; conservative surgery; borderline ovarian; epithelial ovarian cancer

\section{Introduction}

The aim of conservative and functional surgery in an oncology setting is to preserve an organ's functionality and to avoid radical resection when possible. This approach is increasingly used in oncologic gynecologic surgery where fertility-sparing surgery (FSS) aims to preserve the ovarian tissue and the uterus. Moreover, FSS can improve sexual function and the psychological wellbeing of patients, both of which are negatively impacted after cancer diagnosis and treatment [1]. Cryopreservation may also be an option prior to surgery if the risk of gonadal damage is high [2].

Ovarian cancers are classified into epithelial (including borderline ovarian tumors (BOT) and malignant ovarian tumors) and non-epithelial cancer. Although most patients with epithelial ovarian cancer will undergo radical surgery -the gold standard-patients with early-stage disease, BOT, or a non-epithelial tumor could be offered FSS depending on histologic subtypes and prognostic factors [3,4].

The aim of this systematic review is to assess safety and fertility outcomes of FSS in the treatment of ovarian cancer. 


\section{Materials and Methods}

The MEDLINE, PubMed, Cochrane Library, and Cochrane ("Cochrane Reviews") databases were queried with the following terms: ovarian cancer, fertility sparing surgery, conservative surgery, borderline ovarian, epithelial ovarian cancer, mucinous ovarian cancer, serous ovarian cancer, non-epithelial ovarian cancer, germ-cell tumor, sex cord stromal tumor, dysgerminomas, endodermal sinus tumor, malignant teratoma, granulosa cell tumor, Sertoli-Leydig cell tumor, and theca cell tumor. The database search was further supplemented with original articles, reviews, and meta analyses, including the studies cited therein. Only articles published in English or French between 1985 and 15 January 2021 were included.

\section{Borderline Ovarian Tumors}

\subsection{Modalities of Fertility-Sparing Surgery and Clinical Outcomes}

BOT predominantly affects younger women of childbearing age for whom fertility is a major issue. However, the current standard treatment of BOT consists of total abdominal hysterectomy and bilateral salpingo-oophorectomy, peritoneal cytology, omentectomy, and multiple peritoneal biopsies. Adjuvant therapy is not usually necessary unless invasive peritoneal implants are detected [5]. While the prognosis of BOT is excellent, late recurrences (after 5 or 10 years) can occur [6]. FSS in patients with BOT consists of preserving the uterus and at least part of one ovary. In 2013, Daraï et al. conducted a review to analyze the outcomes of FSS (salpingo-oophorectomy or cystectomy) in patients with BOT [7]. They concluded that the risk of relapse was higher after FSS compared with standard treatment, with a global recurrence risk estimated at $13 \%$ (95\% Confidence Interval (CI) 10-16\%). The recurrence rate was correlated with the type of FSS performed with a higher risk (between 10 and $42 \%$ ) observed in patients undergoing cystectomy [7]. Nevertheless, some authors report similar recurrence rates for cystectomy and salpingo-oophorectomy. Palomba et al. [8,9] conducted a randomized trial in 32 patients who underwent laparoscopy for bilateral serous BOT. The patients were randomized into two groups: bilateral cystectomy or unilateral salpingo-oophorectomy on the largest lesion and contralateral cystectomy. They found no difference between the procedures in terms of the cumulative recurrence rates with a follow-up of 81 months. However, although the cumulative pregnancy rate and cumulative probability of a first pregnancy were higher in the group of patients treated with bilateral cystectomy [8], time to first recurrence was shorter and the rate of radical treatment of the recurrence was higher in this group [9]. This study therefore suggests that patients with bilateral serous BOT who wish to conceive should undergo bilateral cystectomy if technically feasible.

The optimal FSS treatment for women with BOT would thus be unilateral adnexectomy, which is associated with a lower risk of relapse. Women with bilateral serous tumors and/or with only one ovary (previous history of adnexectomy) can undergo initial cystectomy and, in case of BOT relapse on the remaining ovary, another cystectomy could be performed to preserve fertility. In this case, a complete preoperative workup should be performed, including:

(1) Magnetic resonance imaging (MRI) to assess possible healthy functional ovarian tissue.

(2) An oncofertility consultation to discuss whether a preoperative fertility preservation technique could be performed.

\subsection{Survival of Patients after Fertility-Sparing Surgery}

We have seen that FSS is associated with a higher recurrence rate compared to radical treatment but it does not affect survival rates because most recurrences are also borderline and can be managed by further surgery. Bendifallah et al. developed a nomogram to predict recurrence in patients with early- and advanced-stage mucinous and serous BOT. An increased risk of recurrence was associated with the surgical procedure (radical vs. 
FSS); International Federation of Gynecology and Obstetrics (FIGO) stage; age at diagnosis; histologic subtype; and completeness of surgery [10].

Nevertheless, a major challenge is to identify women at risk of invasive recurrence, which can be lethal. In the literature, 47 cases of women with BOT progressing to invasive carcinoma have been described with an estimated risk of progression at around 2-3\% [11]. Twenty of these invasive recurrences were observed in patients with serous BOT (mean time to progression: 75 months (range, 11-310)), 24 with mucinous BOT (mean time to progression: 33 months (range, 5-82)), and in three patients of unknown histologic subtype. Recurrences associated with mucinous BOT, though less frequent, were more likely to be invasive. In a recent analysis of 212 patients with advanced stages of BOT, the largest series of patients to date [12], of the $38(58 \%)$ patients who underwent FSS and who experienced recurrence, eight had invasive disease (three patients died). Compared with radical surgery, the use of FSS was a prognostic factor for disease-free survival $(p<0.0001)$ but did not affect overall survival, as mentioned above.

A micropapillary pattern and mucinous subtype were found to be associated with a higher rate of progression to invasive disease after FSS in a large series of women with stage I BOT [13]. A recent study by Jia et al. compared FSS (either bilateral cystectomy or unilateral oophorectomy/cystectomy) and radical surgery in patients with bilateral serous BOT who self-selected one of the three treatment groups after preoperative counseling. The authors reported that a preoperative cancer antigen (CA)-125>300 U/mL, fertility preservation, and micropapillary pattern were independently associated with a poor disease-free survival on multivariate analysis ( $p=0.001,0.03$ and 0.026 , respectively) [14]. Fourteen patients $(15 \%)$ experienced invasive recurrence which was significantly associated with a micropapillary pattern $(p=0.006)$ [14]. Nevertheless, it is important to point out that only 41 patients $(43.6 \%)$ in this series received complete staging during their initial surgery, without a second look, implying that the FIGO stage and number of patients with extraovarian implants might have been underestimated.

The risk of recurrence is lower in patients with mucinous BOT but, when recurrence occurs, it tends to be more invasive. Among the 47 patients with BOT who underwent a cystectomy and developed invasive disease, five of the 11 patients with serous BOT were alive and disease-free at the end of follow-up compared with one of the nine patients with mucinous BOT [11]. There was a higher rate of extra-abdominal metastases as the first recurrence site in the patients with mucinous BOT (four pleural, lung or bone metastases). None of the first recurrence sites were extra-abdominal in the patients with invasive serous BOT [11]. These results suggest that women with mucinous BOT should undergo initial unilateral salpingo-oophorectomy, whereas cystectomy is an acceptable option for women with serous BOT, which has a lower risk of lethal recurrence, in the absence of other high-risk factors.

In a large German series of 950 patients, two-thirds of whom had serous BOT $(n=694)$ and just under one-third mucinous BOT $(n=290), 2.3 \%$ of the lesions transformed into histologically proven invasive disease. In this series, five-year progression-free and overall survival rates were $12 \%$ and $50 \%$, respectively [15].

\subsection{Fertility Results after Fertility-Sparing Surgery}

The observed pregnancy rates after FSS for patients with BOT and a desire for pregnancy lie between 32 and 88\% (Table 1) [12,14,16-27]. Three main factors impact fertility rates: the type of FSS performed, the patient's age, and the histologic subtype of the tumor.

As mentioned above, both the cumulative pregnancy rate and cumulative probability of a first pregnancy were found to be higher after cystectomy compared with salpingooophorectomy and collateral cystectomy [8,9]. As already mentioned above, cystectomy should therefore be the treatment of choice for women with serous BOT who wish to become pregnant. 
Table 1. Fertility results after fertility-sparing surgery in series of women with borderline ovarian tumors and a desire to conceive.

\begin{tabular}{|c|c|c|}
\hline & Fertility-Sparing Surgery $(n)$ & Pregnancy Rate (\%) \\
\hline Boran et al. (2005) [16] & 25 & \\
\hline Early & 25 & 40 \\
\hline Advanced & 0 & \\
\hline Fauvet et al. (2005) [17] & 62 & \\
\hline Early & 62 & 32 \\
\hline Advanced & 0 & \\
\hline Park et al. (2009) [18] & 184 & \\
\hline Early & 181 & 73 \\
\hline Advanced & 3 & \\
\hline Kanat-Pektas et al. (2011) [19] & 55 & 52 \\
\hline Koskas et al. (2011) $\left(^{*}\right)[20]$ & 31 & 38 \\
\hline Song et al. (2011) [21] & 155 & \\
\hline Early & 150 & 88 \\
\hline Advanced & 5 & \\
\hline Lee et al. (2017) [22] & 108 & \\
\hline Early & 105 & 81 \\
\hline Advanced & 3 & \\
\hline Delle Marchette et al. (2019) [23] & 535 & \\
\hline Early & 438 & 84 \\
\hline Advanced & 97 & \\
\hline Lu et al. (2019) [24] & 21 & \\
\hline Early & 0 & 40 \\
\hline Advanced & 21 & \\
\hline Candotti et al. (2020) [25] & 85 & \\
\hline Early & 74 & 73 \\
\hline Advanced & 11 & \\
\hline Chevrot et al. (2020) [26] & 52 & \\
\hline Early & 30 & 63 \\
\hline Advanced & 22 & \\
\hline Jia et al. (2020) [14] & 79 & \\
\hline Early & 43 & 47 \\
\hline Advanced & 36 & \\
\hline Gouy et al. (2020) [12] & 65 & \\
\hline Early & 0 & 69 \\
\hline Advanced & 65 & \\
\hline Plett et al. (2020) [27] & 95 & \\
\hline Early & 77 & 82.9 \\
\hline Advanced & 18 & \\
\hline
\end{tabular}

* Only patients with mucinous borderline ovarian tumors in this series. The observed pregnancy rates are between 32 and $88 \%$.

Secondly, the chances of becoming pregnant decrease with age. Fauvet et al. [17] showed that spontaneous fertility outcomes were poorer in women over 40 years of age. Similarly, Kanat-Pektas et al. [19] reported that the median age of patients who conceived was lower than that of patients who could not ( 36 vs. 45 years). Nevertheless, it is important to take into account that neither of these studies provided sufficient data about ovarian reserve (antral follicle count or serum anti-Müllerian hormone (AMH) levels). In the large German series, Trillsch et al. reported that the younger patients of child-bearing age with relapse were at a higher risk of disease recurrence despite favorable survival outcomes [28]. In a longitudinal study from the French National Cancer Network [26] reporting 52 patients aged 18 to 42 years who underwent FSS for BOT and wished to become pregnant, two- 
thirds of the patients had a live birth after FSS. However, both recurrence and live-birth rates were independent of age, and the authors did not identify a specific age as a cut-off for risk of recurrence, or a time from surgery after which more radical surgery should be undertaken to reduce the risk of recurrence. As almost a quarter of the live births occurred after recurrence, with no further events up to the end of the study period, these results are in line with the recommendation to perform a second FSS after recurrence of a local BOT for women who desire to become pregnant.

Thirdly, in a study investigating whether fertility outcome was related to age, tumor histology or type of surgery, Kanat-Pektas et al. [19] noted that fertility results were better in patients with non-serous (mainly mucinous) BOT: $87 \%$ of the women conceived in the non-serous BOT group compared with $13 \%$ in the group composed mainly of women with serous BOT. This can be explained by the fact that patients with serous BOT are more likely to have bilateral tumors, peritoneal disease or a previous history of infertility which can affect subsequent fertility [29]. Higher pregnancy rates were reported in an Asian series where women with mucinous tumors are more likely to be treated with FSS than elsewhere.

Finally, a laparoscopic approach and a 2- or 3-step surgical procedure (initial, restaging, second look) may also affect fertility rates, although there are no specific data to support this. Further studies are thus merited. A nomogram designed to predict the live-birth rate after FSS for patients with BOT includes FIGO stage, age at diagnosis, histologic subtype, and type of surgery [30].

In a meta-analysis, Jiao et al. reported that the risk of recurrence was significantly higher in patients with unilateral cystectomy (odds ratio (OR), 2.49; 95\% CI, 1.86-3.33) or serous BOT (OR, 3.15; 95\% CI, 1.97-5.02). The surgical approach, i.e., laparoscopy or laparotomy, did not affect the risk of recurrence (OR, 0.96; 95\% CI, 0.57-1.60) [31].

Some patients with BOT who have FSS will experience infertility. In this case, the following question arises: as some studies suggest that infertility treatment, and more specifically clomiphene citrate, are implicated in the genesis of gynecologic cancers, can these women be offered assisted reproductive technology (ART)? However, in vitro fertilization (IVF) procedures have not been associated with an increased risk of BOT or ovarian cancer rates [32]. Furthermore, in vitro data suggest that neither gonadotropins nor high doses of estrogen induce proliferation of borderline cell cultures [33].

Therefore, the answer to the question is that ART is an option for women with BOT-associated infertility even though only a few authors have reported their experiences $[9,17,20,34-48]$.

Most of these studies concern IVF rather than simple ovarian stimulation. A literature review of these series [7] found a pooled estimate for pregnancy of $80 \%$ (95\% CI: 68-92\%), and a pooled estimate for recurrence of $23 \%$ (95\% CI: 6-39\%). This low rate of recurrence is probably because women who are eligible for ART tend to have a better prognosis and early-stage BOT. Overall, women with BOT who wish to conceive should be followed in a specialized center with associating oncologists and fertility experts who can assess the feasibility of FSS on an individual basis along with alternative options to preserve fertility, including ART. Figure 1 summarizes the various options in this setting.

Finally, it is worth focusing on BOT in children and adolescents. A recent literature review identified 300 cases of BOT occurring in children and young women aged between 3 and 25 years (15 of whom were premenarchal) [49]. The largest series was a SEER (Surveillance, Epidemiology and End Results) Database study from Nasioudis et al. with 114 patients [50] which found that serous histology was more common than mucinous in this age group (53.5\% vs. $44.8 \%$ ). However, while pediatric BOTs are rare and difficult to predict preoperatively, prognosis is excellent after FSS even in patients with advanced stages. FSS should therefore be the gold standard of treatment in children and adolescents. 


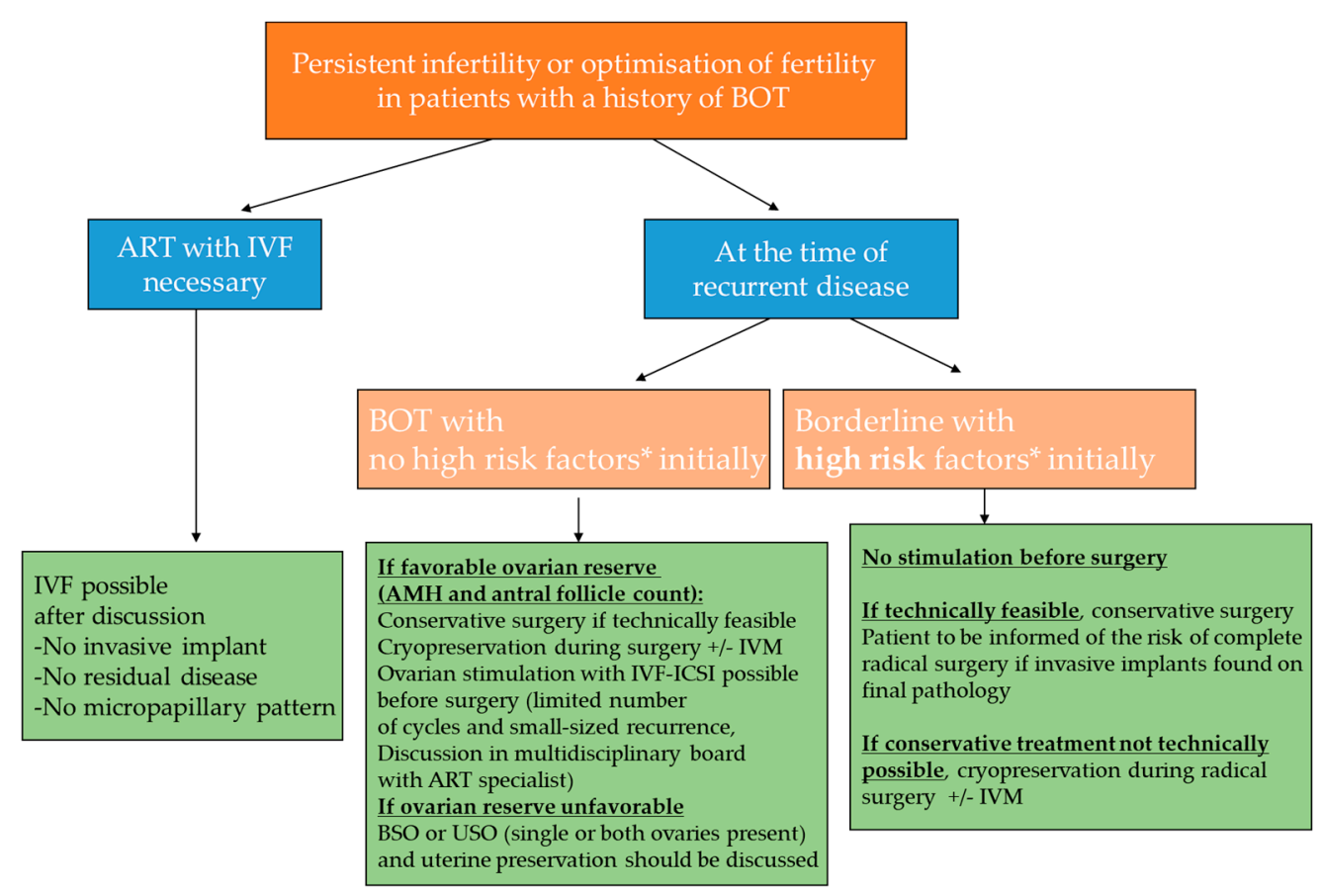

Figure 1. Management of infertility (or optimization of infertility) in a young patient with previous history of BOT (ART, assisted reproductive technology; IVF, in vitro fertilization; ICSI, intracytoplasmic sperm injection; IVM, in vitro maturation; BSO, bilateral salpingo-oophorectomy; USO, unilateral salpingo-oophorectomy; AMH: anti-Mullerian hormone; * High-risk recurrent borderline tumor: defined by a recurrent case presenting radiologic (on magnetic resonance imaging) or clinical (recurrence associated with implants) suspicious lesion at the time of the recurrence or histologic high risk factors (peritoneal implants, mucinous tumor with intraepithelial carcinoma, micropapillary patterns, stromal microinvasion) during the treatment of the first tumor (ref Darai et al. Human reprod 2013).

\section{Epithelial Ovarian Cancer}

\subsection{Indications of Fertility-Sparing Surgery}

As for BOT, the standard surgical procedure for women with EOC is radical: hysterectomy with bilateral salpingo-oophorectomy. It is somewhat difficult to analyze the outcome of FSS in this setting because many of the reported series either mix epithelial and non-epithelial ovarian cancers, or include invasive cancers and BOT, considering them as epithelial. Very few series report FSS outcomes in EOC exclusively.

Table 2 provides a summary of reported recurrence risk and survival rates after FSS for patients with EOC [51-81]. 
Table 2. Literature review of recurrence risk and survival rates after fertility-sparing surgery for patients with epithelial ovarian cancer.

\begin{tabular}{|c|c|c|c|c|c|c|c|c|c|c|c|}
\hline & $\begin{array}{c}\text { Number of Patients } \\
n\end{array}$ & Histologic Type & $\begin{array}{c}\text { Stage IA } \\
n\end{array}$ & $\begin{array}{c}\text { Stage IB } \\
n\end{array}$ & $\begin{array}{c}\text { Stage IC } \\
n\end{array}$ & $\underset{n}{\text { Grade } 1}$ & $\begin{array}{c}\text { Grade } 2 \\
n\end{array}$ & $\begin{array}{c}\text { Grade } 3 \\
n\end{array}$ & $\begin{array}{l}\text { Recurrence } \\
n(\%)\end{array}$ & $\begin{array}{l}\text { Death } \\
n(\%)\end{array}$ & $\begin{array}{c}5 \text { Year Recurrence Free } \\
\text { Survival } \\
\%\end{array}$ \\
\hline $\begin{array}{c}\text { Zanetta et al. } \\
\text { (1997) [51] }\end{array}$ & 56 & All types & 32 & 2 & 22 & 35 & 14 & 7 & $5(8.9)$ & $3(5.3)$ & \\
\hline $\begin{array}{l}\text { Schilder et al. } \\
\text { (2002) [52] }\end{array}$ & 52 & All types & 42 & 0 & 10 & 38 & 9 & 5 & $\begin{array}{c}5(9.6) \\
\text { S 2/10, M } \\
2 / 25, \mathrm{E} \\
1 / 10, \mathrm{CC} \\
0 / 5\end{array}$ & $2(3.8)$ & \\
\hline $\begin{array}{l}\text { Morice et al. } \\
\text { (2005) [53] }\end{array}$ & 34 & All types & 30 & 0 & 3 & 15 & 15 & 4 & $\begin{array}{c}10(29.4) \\
\mathrm{S} 2 / 3, \mathrm{M} \\
5 / 21, \mathrm{E} 1 / 5 \\
\mathrm{CC} 1 / 2 \\
\end{array}$ & $4(11.7)$ & \\
\hline $\begin{array}{l}\text { Borgfeldt et al. } \\
\text { (2007) [54] }\end{array}$ & 11 & All types & 10 & 0 & 1 & 9 & 1 & 1 & $1(9)$ & $1(9)$ & \\
\hline Park et al.(2008) [55] & 62 & All types & 36 & 2 & 21 & 48 & 5 & 9 & $\begin{array}{c}11(17.7) \\
\text { S } 0 / 7, \mathrm{M} \\
7 / 41, \mathrm{E} 1 / 8 \\
\text { CC } 2 / 4\end{array}$ & $6(9.7)$ & \\
\hline $\begin{array}{l}\text { Schlaerth et al. } \\
\text { (2009) [57] }\end{array}$ & 20 & All types & 11 & 0 & 9 & 15 & 5 & 1 & $3(15)$ & $3(15)$ & \\
\hline $\begin{array}{l}\text { Kwon et al. } \\
\text { (2009) [58] }\end{array}$ & 21 & All types & 17 & 0 & 4 & 16 & 3 & 2 & $1(4.7)$ & 0 & \\
\hline $\begin{array}{l}\text { Wright et al. } \\
(2009)^{*}[59]\end{array}$ & 432 & All types & 370 & 0 & 62 & 157 & 92 & 37 & NA & & $94 \%$ \\
\hline $\begin{array}{l}\text { Satoh et al. } \\
\text { (2010) [60] }\end{array}$ & 211 & All types & 126 & 0 & 85 & 160 & 15 & 36 & $\begin{array}{c}18(8.5) \\
\text { S 3/27, M } \\
6 / 126, \mathrm{E} \\
4 / 27, \mathrm{CC} \\
5 / 30\end{array}$ & $5(2.4)$ & \\
\hline $\begin{array}{c}\text { Kajiyama et al. } \\
\text { (2010) [61] }\end{array}$ & 60 & All types & 30 & 1 & 29 & 41 & 7 & 12 & $8(13.3)$ & $7(11.7)$ & \\
\hline $\begin{array}{l}\text { Hu et al. } \\
\text { (2011) [62] }\end{array}$ & 94 & All types & 46 & 8 & 28 & 64 & 13 & 1 & $2(2.4)$ & NA & \\
\hline
\end{tabular}


Table 2. Cont.

\begin{tabular}{|c|c|c|c|c|c|c|c|c|c|c|c|}
\hline & $\begin{array}{c}\text { Number of Patients } \\
n\end{array}$ & Histologic Type & $\begin{array}{l}\text { Stage IA } \\
n\end{array}$ & $\begin{array}{l}\text { Stage IB } \\
n\end{array}$ & $\begin{array}{c}\text { Stage IC } \\
n\end{array}$ & $\underset{n}{\text { Grade } 1}$ & $\underset{n}{\text { Grade } 2}$ & $\begin{array}{c}\text { Grade } 3 \\
n\end{array}$ & $\begin{array}{l}\text { Recurrence } \\
n(\%)\end{array}$ & $\begin{array}{l}\text { Death } \\
n(\%)\end{array}$ & $\begin{array}{c}5 \text { Year Recurrence Free } \\
\text { Survival } \\
\%\end{array}$ \\
\hline $\begin{array}{l}\text { Kajiyama et al. } \\
\text { (2011) [63] }\end{array}$ & 40 & Mucinous & 27 & 0 & 14 & NA & NA & NA & NA & NA & $97.5 \%$ \\
\hline $\begin{array}{l}\text { Cheng et al. } \\
\text { (2012) [64] }\end{array}$ & 17 & All types & 10 & 0 & 6 & 15 & 2 & 0 & $1(5.9)$ & 0 & \\
\hline $\begin{array}{c}\text { Fruscio et al. } \\
(2013,2016)[65,66]\end{array}$ & 240 & All types & 130 & 2 & 105 & 141 & 70 & 29 & $\begin{array}{c}27(11.2) \\
\mathrm{S} 11 / 62, \mathrm{M} \\
8 / 99, \mathrm{E} \\
6 / 60, \mathrm{CC} \\
2 / 17\end{array}$ & $11(4.6)$ & \\
\hline $\begin{array}{c}\text { Kashima et al. (2013) } \\
\text { [67] }\end{array}$ & 18 & All types & 0 & 0 & 18 & 14 & 0 & 4 & $5(27.7)$ & $4(22.2)$ & \\
\hline $\begin{array}{c}\text { Kajiyama et al. (2014) } \\
\text { [68] }\end{array}$ & 94 & All types & 43 & 0 & 51 & 59 & 14 & 4 & 14 & 11 & $84.3 \%$ \\
\hline $\begin{array}{l}\text { Lee et al. } \\
(2015)[69]\end{array}$ & 35 & Mucinous & 21 & 0 & 13 & 27 & 5 & 1 & $6(17.1)$ & & $91 \%$ \\
\hline $\begin{array}{l}\text { Ditto et al. } \\
\text { (2015) [70] }\end{array}$ & 70 & All types & 46 & 2 & 15 & 36 & 24 & 9 & NA & & $98 \%$ \\
\hline $\begin{array}{l}\text { Bentivegna et al. * } \\
\text { (2016) [71] }\end{array}$ & 673 & All types & 396 & 46 & 231 & $442 * *$ & $126^{* *}$ & $58^{* *}$ & $\begin{array}{c}79 / 673(12) \\
\text { S 20/128 } \\
(16) \\
\text { M } 30 / 344 \\
(9) \\
\text { E } 16 / 128 \\
(12) \\
\text { CC } 10 / 60 \\
(17)\end{array}$ & & \\
\hline $\begin{array}{l}\text { Gouy et al. } \\
\text { (2017) [72] }\end{array}$ & 21 & Mucinous & 9 & 0 & 12 & 9 & 5 & 1 & $2(9,5 \%)$ & 0 & $\begin{array}{l}\text { 90.5\% (median follow: } 46 \\
\text { months }(r 1-169)\end{array}$ \\
\hline $\begin{array}{l}\text { Jiang et al. } \\
\text { (2017) [73] }\end{array}$ & 52 & All types & & 9 & 33 & 45 & 4 & 1 & $5(9,6 \%)$ & NA & $91 \%$ \\
\hline $\begin{array}{l}\text { Melamed et al. (2017) } \\
\text { [74] }\end{array}$ & 825 & All types & 546 & 0 & 279 & 298 & 201 & 111 & & $30(3.6)$ & \\
\hline $\begin{array}{l}\text { Ratanasrithong et al. } \\
\text { (2018) [75] }\end{array}$ & 28 & All types & & & & 17 & 1 & 5 & $4(14.3)$ & $1(3.6)$ & \\
\hline
\end{tabular}


Table 2. Cont.

\begin{tabular}{|c|c|c|c|c|c|c|c|c|c|c|c|}
\hline & $\begin{array}{c}\text { Number of Patients } \\
n\end{array}$ & Histologic Type & $\begin{array}{c}\text { Stage IA } \\
n\end{array}$ & $\begin{array}{c}\text { Stage IB } \\
n\end{array}$ & $\begin{array}{c}\text { Stage IC } \\
n\end{array}$ & $\underset{n}{\text { Grade } 1}$ & $\underset{n}{\text { Grade } 2}$ & $\underset{n}{\text { Grade } 3}$ & $\begin{array}{c}\text { Recurrence } \\
n(\%)\end{array}$ & $\begin{array}{l}\text { Death } \\
n(\%)\end{array}$ & $\begin{array}{c}5 \text { Year Recurrence Free } \\
\text { Survival } \\
\%\end{array}$ \\
\hline $\begin{array}{l}\text { Hanatani et al. (2019) } \\
\text { [76] }\end{array}$ & & All types & 325 & & & & & & & & \\
\hline $\begin{array}{c}\text { Kajiyama et al. (2019) } \\
\text { [77] }\end{array}$ & 8 (with cystectomy) & All types & 3 & 0 & 5 & 8 & 0 & 0 & $2(25)$ & $1(12.5)$ & \\
\hline $\begin{array}{l}\text { Bogani et al. } \\
(2020)[78]\end{array}$ & 34 & All types & 21 & 2 & 9 & \multicolumn{2}{|c|}{28} & 6 & 7 (20.6) & $2(5.9)$ & \\
\hline $\begin{array}{l}\text { Watanabe et al. } \\
\text { (2020) [80] }\end{array}$ & 29 & All types & 14 & 0 & 15 & 13 & 10 & 3 & $5(17.2)$ & $2(6.9)$ & $\begin{array}{c}90.9 \text { for IA/IC1 } \\
43.8 \text { for IC3 }\end{array}$ \\
\hline $\begin{array}{l}\text { Zhang et al. } \\
\text { (2020) [81] }\end{array}$ & 5 & Mucinous & 5 & 0 & 0 & & & & 0 & 0 & \\
\hline
\end{tabular}

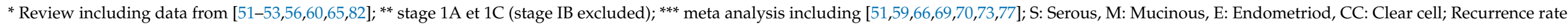
by histologic type has been indicated for series including more than 10 patients with recurrence. 
P DiSaia was the first to offer FSS for EOC in highly selected patients, i.e.: with wellencapsulated stage IA EOC without peritumoral adhesions, ovarian capsule lymphatic channels and/or mesovarium invasion, and negative peritoneal washings; with a desire to conceive; and a willingness to undergo close gynecologic follow-up [83].

The first series specifically describing FSS in women with EOC was published by Colombo et al. [82] in 1994 and by Zanetta et al. [51] in 1997. Together they included 56 selected patients (i.e., stage IA to IC disease, any grade) who underwent FSS. Survival was excellent: for example, Colombo et al. reported a five-year survival rate of $96 \%$.

An American multicenter study comprising 52 patients with early-stage EOC who underwent FSS [52] reported estimated five-year and 10-year overall survival rates of $98 \%$ and $93 \%$, respectively. The authors went on to suggest that FSS could be performed in stage I EOC of any grade.

In 2005, a French multicenter retrospective study described a series of 34 patients who had undergone FSS for EOC [53] with a systematic review of slides, complete staging surgery and chemotherapy for patients with stage $\geq \mathrm{IC}$. They reported one case of recurrence in the 13 patients with stage I grade 1 disease, and eight cases of recurrence in 20 patients with grade $2 / 3$ stage IA to IC disease. They concluded that FSS should be reserved for patients with a FIGO stage $\leq$ IA.

A study by Park et al. in 2008 [55], including 62 patients with EOC, 59 of whom had early-stage disease, found that patients with stage IC or grade 3 tumors had significantly poorer survival (5-year survival: $88 \%$ ). The authors concluded that FSS was an option in young patients with EOC of stages IA-C, grades 1-2.

A large Japanese multicenter study [60] of 211 patients with EOC who underwent FSS in 30 institutions reported five-year recurrence-free survival rates of $97.8 \%$ for stage IA with favorable histology (grade 1, grade 2, not clear-cell), 100\% for stage IA clear-cell, 33.3\% for stage IA grade 3, 92.1\% for stage IC with favorable histology, $66 \%$ for stage IC clear-cell, and $66.7 \%$ for stage IC grade 3 . The authors suggested that FSS was an option in patients with stage IA disease either with a favorable histologic subtype or clear-cell histology, or in patients with stage IC with a favorable histology only. However, they specified that FSS should be avoided in patients with grade 3 tumors.

A large analysis of FSS with preservation of the ovary in stage IA or IC disease in the SEER database confirmed that FSS did not affect survival rates [59]. Nevertheless, the authors pointed out that "to detect a $20 \%$ difference in survival for patients with stage IC disease, a cohort of 1282 patients with 52 deaths is required". Therefore, it is not possible to make firm conclusions about the safety of FSS in patients with stage IC disease since the published series to date are all underpowered.

Another large retrospective study was published by Fruscio et al. in 2013 and updated in $2016[65,66]$. They found that the oncologic prognosis was the same for the 240 patients treated with FSS as for the patients who underwent radical treatment. Prognosis was worse in women with grade 3 but independent of the type of surgery. The authors conclude that FSS can be offered to all young patients when the tumor is limited to the ovaries. Patients with grade 3 tumors are more likely to experience distant recurrences and these patients should be closely monitored.

These data have been confirmed by more recent studies. In 2017, Jiang et al. published a retrospective study of 108 patients of reproductive age ( $\leq 40$ years) diagnosed with stage I EOC who were treated either with FSS (48.1\%) or radical surgery $(51.9 \%)$. After a median follow-up of 83 months, multivariate analysis revealed that the only independent risk factors for disease-free survival and tumor-specific survival were grade 3 or clear-cell carcinoma. The authors thus concluded that FSS was safe for patients of reproductive age with grade 1-2, stage I EOC [73].

The largest study was published by Melamed et al. in 2017 [74]. This American cohort study, using the National Cancer Database, identified 1726 women with stage IA and unilateral IC EOC of whom $825(47.8 \%)$ underwent FSS. FSS was not associated with hazard of death (hazard ratio $0.80,95 \%$ CI $0.49-1.29, p=0.36$ ). Of particular interest, they 
observed that in patients with high-risk features such as a clear-cell histology, grade 3 , or stage IC, 10-year survival was $80.5 \%$ (95\% CI 68.5-88.3) among women who underwent FSS and $83.4 \%$ (95\% CI 76.0-88.7) among those who had conventional surgery (hazard ratio $0.86,95 \%$ CI $0.49-1.53, p=5.61$ ). The authors concluded that compared with conventional surgery, FSS was not associated with an increased risk of death in young women with stage I EOC. Nonetheless, given the limited number of patients with clear-cell and other high-grade histology included in the study, the authors recommended that preoperative counseling should warn women that the safety of FSS is less certain in patients with clear-cell tumors or other high-grade histology [74]. In 2017, Gouy et al. published a retrospective survey concerning 21 patients with unilateral mucinous ovarian cancer (mOC) who underwent unilateral salpingo-oophorectomy and who, with one exception, completed peritoneal staging surgery [72]. After a median time of follow-up of 46 months (range, 1-179), recurrence was observed in two patients: one who had an expansile-type tumor and the other an infiltrative type. Based on these results, the authors suggest that the type of mOC (i.e., infiltrative or expansile) does not impact the oncologic outcomes in stage I mOC, and that FSS could be offered for women with early-stage infiltrative-type tumors using the same criteria as for expansile-type tumors.

Similarly, Hanatani et al. presented the results of a retrospective study including 583 patients ( 325 patients with cancer and 258 with BOT) $<40$ years old. In this study, multivariate analysis revealed that the independent prognostic factors for overall survival were age, stage, histology, and ascitic fluid cytology, but not FSS [76].

More recently, in 2020, Bogani et al. investigated the 10-year outcomes in a large series of women with apparent early-stage ovarian cancer who underwent either FSS $(n=34)$ or radical surgery $(n=148)$. Their results showed that the type of surgery (FSS vs. radical) did not affect survival in the high-risk group ( $\geq$ grade 3 or $\geq$ stage IC) [78].

Finally, a meta analysis by Liu et al. [79] including eight studies demonstrated that the type of surgery did not seem to affect overall or disease-free survival for patients with stage 1 EOC. Neither did disease stage, tumor grade or histology appear to influence outcomes [79].

Watanabe et al. published a retrospective study including 29 EOC patients (stage IA, $n=14$; stage IC1 $n=6$; stage IC $3, n=9$ ) aged $\leq 40$ years who had undergone FSS [80]. The respective 5-year relapse-free and overall survival rates were $90.9 \%$ and $100 \%$, respectively, for stage IA/IC1, and $43.8 \%$ and $87.5 \%$ for stage IC3. Significant differences in relapse-free survival were observed between patients with stage IA/IC1 and IC3 $(p=0.026)$. However, there was no significant difference in overall survival between patients with $1 \mathrm{~A} / 1 \mathrm{C} 1$ and those with 1C3 $(p=0.712)$. According to the authors, these results confirm that FSS may be an acceptable treatment method for stage IA and IC1 EOC, exhibiting a favorable reproductive outcome. However, the safety of FSS for treating stage IC3 EOC is uncertain and warrants further investigation [80].

While prognosis remains poor for women who experience recurrence outside the preserved ovary after FSS [84], prognosis is good if the recurrence is limited to the preserved ovary [85].

Patients with a "borderline" indication for FSS (i.e., stage IA grade 3 disease, stage IB or IC grade 2 or 3 disease) could undergo removal of both ovaries and preservation of the uterus (including no uterine curettage for staging), and subsequently attempt pregnancy using egg donation. This approach has not been explored to date in EOC but deserves to be evaluated. In the SEER database analysis, uterine preservation was not found to impact survival in women with stage IA or IC disease [59].

In light of recent data $[86,87]$, the best treatment option for patients with a clear-cell stage I tumor should be discussed by dedicated tumor boards on a case-by-case basis. In France, for example, a national expert website has been developed (www.ovaire-rare.org), in which cases of rare ovarian tumors and FSS for EOC can be discussed.

FSS is obviously not performed in women with disease extending beyond the ovaries because of the high risk of recurrence [53,55]. Nevertheless, some cases have been reported 
in the literature and were analyzed in the review by Petrillo et al. [87]. The authors report 21 patients with stage II-III disease who underwent FSS. Nine of the patients $(42.8 \%)$ experienced recurrence and five $(23.8 \%)$ died of the disease. Radical surgery thus remains the standard treatment for advanced EOC.

FSS generally consists of the conservation of at least the contralateral ovary and the uterus with a staging surgery. However, information about the clinical outcome in women who undergo a cystectomy as a fertility-preserving option is lacking. Recently, Kajiyama et al. [77] presented the results of a retrospective study including eight patients with early-stage EOC treated with cystectomy as FSS. Two of the patients (IA, endometrioid histology, and IC3 mucinous histology) experienced recurrence in the pelvic cavity and bilateral ovaries, respectively, and one died of the disease. The authors concluded that more research is required to clarify the applicability of cystectomy for FSS in this setting.

\subsection{Fertility Results}

Table 3 summarizes the fertility results found in the literature.

Table 3. Fertility outcomes after fertility-sparing surgery for patients treated for epithelial ovarian cancer.

\begin{tabular}{|c|c|c|c|c|}
\hline Author (Year) & $\begin{array}{l}\text { Number of Patients } \\
n\end{array}$ & $\begin{array}{c}\text { Number of Patients Wishing to } \\
\text { Conceive } \\
n(\%)\end{array}$ & $\begin{array}{c}\text { Number of Pregnant } \\
\text { Patients } \\
n(\%)\end{array}$ & $\begin{array}{c}\text { Live Births } \\
n\end{array}$ \\
\hline Schilder et al. (2002) [52] & 52 & $24(46 \%)$ & $17(71 \%)$ & 26 \\
\hline Park et al. (2008) [55] & 62 & $19(30 \%)$ & $15(79 \%)$ & 22 \\
\hline Schlaerth et al. (2009) [57] & 20 & $15(75 \%)$ & $6(40 \%)$ & 9 \\
\hline Kwon et al. (2009) [58] & 21 & $5(24 \%)$ & $5(100 \%)$ & 5 \\
\hline Satoh et al. (2010) [60] & 211 & $84(40 \%)$ & $45(53 \%)$ & 56 \\
\hline Cheng et al. (2012) [64] & 17 & $8(47 \%)$ & $5(62 \%)$ & 6 \\
\hline Fruscio et al. $(2013,2016)[65,66]$ & 240 & $105(44 \%)$ & $84(80 \%)$ & 91 \\
\hline Kashima et al. (2013) [67] & 18 & $10(55 \%)$ & $5(50 \%)$ & 7 \\
\hline Gouy et al. (2017) [72] & 21 & $21(100 \%)$ & $4(19 \%)$ & 6 \\
\hline Jiang et al. (2017) [73] & 52 & $34(65 \%)$ & $32(94 \%)$ & 28 \\
\hline Ratanasrithong et al. (2018) [75] & 28 & $7(25 \%)$ & $4(6 \%)$ & 4 \\
\hline Kajiyama et al. (2019) [77] & 8 & $7(88 \%)$ & $4(6 \%)$ & 4 \\
\hline Total & 802 & $339 / 802(42 \%)$ & $226 / 339(67 \%)$ & 264 \\
\hline
\end{tabular}

Only 12 series have reported fertility data after EOC [52,55,57,58,60,64-67,72,73,75,77]: of the $42 \%$ of patients who wished to be pregnant after FSS (339/802), 67\% achieved pregnancy (226/339), resulting in 264 live births.

Ovarian stimulation or IVF remain contraindicated for women with persistent infertility.

Patient follow-up is based on clinical examination, blood markers, and systematic imaging (abdomino-pelvic ultrasonography).

The interest of completion of surgery after childbearing age (or after 40 years in patients who have not been pregnant) is still under discussion. Nevertheless, to reduce the risk of recurrence, removal of the remaining ovary should be considered in women who no longer intend to conceive, integrating information about BRCA mutations.

\section{Non-Epithelial Ovarian Cancer}

Compared to EOC, non-epithelial malignant tumors are characterized by: 1. disease onset at an early age, and 2. an overall good prognosis (even in case of extra-ovarian disease) due to excellent response to chemotherapy. The tumors can be classified into two main groups: malignant ovarian germ cell tumors (MOGCT) and sex cord stromal tumors (SCST). 


\subsection{Malignant Ovarian Germ Cell Tumors}

Most studies exploring the results of FSS in non-epithelial cancers concern MOGCTs (Table 4) [75,88-109].

Table 4. Literature review of fertility outcomes after fertility-sparing surgery in germ cell tumors (series published after 1995).

\begin{tabular}{|c|c|c|c|c|c|}
\hline Author & $N$ pts & $N$ Conservative & $\begin{array}{c}\text { Menstruation } \\
\text { Maintained }\end{array}$ & $N$ Pregnancies & $\begin{array}{c}N \text { Conservative } \\
\text { II/III/IV }\end{array}$ \\
\hline Peccatori et al. 1995 [88] & 129 & 108 & $?$ & $?$ & 37 \\
\hline $\begin{array}{l}\text { Mitchell et al. * } \\
1999 \text { [89] }\end{array}$ & 69 & 50 & $24 / 26$ & 11 & $?$ \\
\hline $\begin{array}{l}\text { Brewer et al. ** } \\
1999 \text { [90] }\end{array}$ & 26 & 16 & 14 & 5 & $?$ \\
\hline Perrin et al. 1999 [91] & 45 & 45 & $\begin{array}{l}\text { During chemotherapy } \\
50 \% \text { became } \\
\text { amenorrhoeic } \\
96 \% \text { resumed normal } \\
\text { menstrual function on } \\
\text { completion }\end{array}$ & $\begin{array}{l}7 \text { healthy babies in the } \\
\text { chemotherapy group }\end{array}$ & \\
\hline $\begin{array}{l}\text { Tewari et al. } \\
2000 \text { [92] }\end{array}$ & 72 & 46 & $?$ & $?$ & $1^{* * * * *}$ \\
\hline $\begin{array}{l}\text { Low et al. } \\
2000[93]\end{array}$ & 74 & 74 & $43 / 45$ & $19 / 20$ & 19 \\
\hline $\begin{array}{c}\text { Zanetta et al. } \\
2001[94]\end{array}$ & 169 & 138 & $128 / 130$ & 55 in 32 pts & 46 \\
\hline $\begin{array}{l}\text { Tangir et al. } \\
2003 \text { [95] }\end{array}$ & 106 & 64 & $32 / 40 * * *$ & 38 in 29 pts & $\begin{array}{c}11(9 \\
\text { pregnancies })\end{array}$ \\
\hline $\begin{array}{l}\text { Zanagnolo et al. } \\
2004 \text { [96] }\end{array}$ & 55 & 39 & 26 & 11 & 11 \\
\hline $\begin{array}{l}\text { Boran et al. }{ }^{* *} \\
2005[97]\end{array}$ & 23 & 23 & $19 / 23 * * *$ & 6 in 5 pts & 8 (4 pregnancies) \\
\hline $\begin{array}{l}\text { Ayhan et al. * } \\
2005 \text { [98] }\end{array}$ & 29 & 15 & $10^{* * * *}$ & 3 & $?$ \\
\hline $\begin{array}{l}\text { Kang et al. * } \\
2008 \text { [99] }\end{array}$ & 20 & 15 & 15 & 2 & $?$ \\
\hline $\begin{array}{l}\text { De la Motte Rouge et al. * } \\
2008 \text { [100] }\end{array}$ & 52 & 41 & $39 / 40$ & 19 in 12 pts & 4 pregnancies \\
\hline Ertas et al. 2014 [101] & 42 & 31 & $23 / 27$ with chemotherapy & $\begin{array}{l}17 \text { by } 21 \text { patients who } \\
\text { attempted conception }\end{array}$ & 13 \\
\hline $\begin{array}{l}\text { Satoh et al. * } \\
2015 \text { [102] }\end{array}$ & 211 & 157 & $109 / 109$ & 29 in $40 \mathrm{pts}$ & $?$ \\
\hline Yang et al. (2016) [103] & 106 & 59 & 45 & $\begin{array}{c}33 \text { in } 31 \text { pts (39 desired a } \\
\text { pregnancy) }\end{array}$ & \\
\hline Ghalleb et al. (2017) [104] & 1 & 1 & 1 & 3 & 1 \\
\hline Park et al. (2017) [105] & 171 & 171 & $\begin{array}{l}\text { 106/124 patients }(85.5 \%) \\
\text { had regular menstruation, } \\
\text { 12/124 patients }(9.7 \%) \\
\text { had irregular } \\
\text { menstruation, } \\
\text { and } 6 / 124 \text { patients }(4.8 \%) \\
\text { had premature } \\
\text { menopause }\end{array}$ & $\begin{array}{l}15 / 20 \text { patients }(75 \%) \\
\text { succeeded in achieving } 21 \\
\text { pregnancies, } \\
13 / 20 \text { of the patients } \\
(65 \%) \text { gave birth to } 20 \\
\text { healthy babies. }\end{array}$ & 46 \\
\hline $\begin{array}{l}\text { Ratanasrithong et al. (2018) } \\
\text { [75] }\end{array}$ & 22 & 22 & & $\begin{array}{c}4 \text { in } 4 \text { patients (8 desired a } \\
\text { pregnancy) }\end{array}$ & \\
\hline Duhil (2018) et al. ** [106] & 48 & 36 & & $\begin{array}{l}13 \text { patients }(36 \%) \text { had } 22 \\
\text { pregnancies resulting in } \\
17 \text { healthy born children }\end{array}$ & \\
\hline
\end{tabular}


Table 4. Cont.

\begin{tabular}{|c|c|c|c|c|c|}
\hline Author & $N$ pts & $N$ Conservative & $\begin{array}{l}\text { Menstruation } \\
\text { Maintained }\end{array}$ & $N$ Pregnancies & $\begin{array}{c}N \text { Conservative } \\
\text { II/III/IV }\end{array}$ \\
\hline $\begin{array}{l}\text { Lakshmanan et al. (2018) } \\
\text { [107] }\end{array}$ & 39 & 14 & 9 & 1 & \\
\hline Tamauchi et al. (2018) [108] & 105 & 105 & $\begin{array}{c}57 \text { (among } 72 \text { with } \\
\text { chemotherapy, and NA = } \\
13 \text { ) }\end{array}$ & $\begin{array}{l}42 \text { patients ( } 45 \text { desired a } \\
\text { pregnancy) had } 64 \\
\text { pregnancies resulting in } \\
56 \text { healthy born children } \\
\text { (among } 40 \text { patients) }\end{array}$ & 31 \\
\hline Dellino et al. (2020) [109] & 28 & 24 & $\begin{array}{c}\text { Of } 19 \text { women with } \\
\text { chemotherapy, } 15(78 \%) \\
\text { reported regular } \\
\text { menstrual cycles during } \\
\text { and after chemotherapy; } \\
\text { the remaining } 4(21 \%) \\
\text { presented amenorrhea } \\
\text { during chemotherapy but } \\
\text { reported regular cycles } \\
\text { after the end of treatment. }\end{array}$ & $\begin{array}{l}5 \text { of } 5 \text { women who tried } \\
\text { to get pregnant } \\
\text { succeeded spontaneously. }\end{array}$ & 5 \\
\hline
\end{tabular}

* Papers reporting exclusively Endodermal Sinus Tumor or non-dysgerminomatous tumors; ${ }^{* *}$ paper reporting only dysgerminomatous tumors; ${ }^{* * *}$ menstruation considered as "similar" to before chemotherapy; *** five patients excluded from menstruation assessment because of lethal recurrence; ${ }^{* * * * *}$ pregnant patient. Pts: patients; ?: unknown data.

The most frequent MGCTs are dysgerminomas, endodermal sinus tumors (EST), malignant teratoma, or mixed subtypes. The standard chemotherapy regimen for such tumors is a combination of bleomycin, etoposide and cisplatin (the BEP regimen). Younger patients are usually managed by FSS after discussion about staging procedures (nodal or peritoneal). Biopsy of the contralateral ovary is not recommended in patients with non-dysgerminoma tumors and a macroscopically normal ovary. The situation is less clear for women with a dysgerminoma because of the risk of occult disease, which is observed in $10 \%$ of patients. For example, Boran et al. observed that two $(11 \%)$ of the 17 patients with macroscopically normal contralateral ovary had occult involvement [97].

Table 4 summarizes the fertility results of series reported after 1995. Most young patients treated by the BEP regimen continue to menstruate and maintain endocrine ovarian function. In the largest series from Satoh et al. [102], all patients who underwent FSS recovered their menstrual cycle. Sixteen of 23 patients receiving BEP $(70.0 \%)$ and 13 of 17 patients receiving non-BEP $(76.5 \%)$ who were nulliparous at FSS and married at the time of investigation (although these are debatable criteria) gave birth to 21 and 19 healthy children, respectively. More recently, Park et al. [105] investigated 171 patients with early $(n=125)$ and advanced $(n=46)$ MOGCTs who underwent FSS, and reported a 5-year disease-free survival rate of $86 \%$, and a 5 -year overall survival rate of $97 \%$. The 5 -year disease-free survival was $84 \%$ for stage I and $89 \%$ for stage II-IV. The 5 -year overall survival was $99 \%$ for stage I and $91 \%$ for stage II-IV. Yolk sac tumor, incomplete surgical staging, and residual tumor were independent prognostic factors. Interestingly, reproductive and obstetric outcomes were evaluable in 124 patients of whom $106(85.5 \%)$ had regular menstruation, $12(9.7 \%)$ had irregular menstruation, and six (4.8\%) had premature menopause. Of the 20 patients who tried to conceive, 15 patients $(75 \%)$ were successful, resulting in 21 pregnancies, and $13(65 \%)$ gave birth to 20 healthy babies. Furthermore, a study by Turkmen et al. [110] concerning 69 patients with stage I and II MOGCTs (56 undergoing FSS) found that surgery type (FSS vs. radical surgery) and lymphadenectomy (performed vs. not performed) did not affect recurrence rates $(p=0.758, p=0.271)$. However, recurrence was linked to surgical outcome (maximal vs. optimal and suboptimal) and type of tumor (dysgerminoma vs. nondysgerminoma) $(p=0.001, p=0.021$, respectively). Such conservative management of a part of one ovary could be considered for patients with bilateral involvement of both ovaries (as in the case of teratomas) or for patients with peritoneal disease treated by adjuvant chemotherapy (particularly in for dysgerminomas or malignant teratoma). 
Completion surgery after childbearing is not necessary in these patients because of the high curability rates.

\subsection{Sex Cord Stromal Tumors}

The most frequent subtypes of SCSTs are granulosa cell, Sertoli-Leydig cell, and thecal cell tumors. Publications of FSS outcomes in women with SCSTs are scarce and mainly consist of case reports or short series [111-122].

In 2007, Zhang et al. published an analysis of the SEER database including 376 women treated for SCST: 71 young patients were treated using uterine preservation for stage I disease. The survival of patients treated by FSS and radical surgery was similar [117].

Two important characteristics of granulosa cell tumors affect FSS: bilaterality is only observed in between $2 \%$ and $8 \%$ of cases [118-122]; and these tumors are often associated with endometrial disorders (hyperplasia or cancers). Therefore, while random biopsies of the contralateral ovary (if macroscopically normal) are not necessary, uterine curettage should be systematically performed. The overall prognosis of granulosa cell tumors is good in early-stage disease (stage IA) and FSS is an option for young patients. However, prognosis is more reserved for women with higher stages (or in the case of ovarian rupture during the initial surgery), and FSS is not recommended in this setting. In 2018, Wang et al. [120] published a retrospective analysis of 113 patients with stage I ovarian granulosa tumor: 61 had FSS and 52 underwent radical surgery. After a median follow-up of 99.2 months (range 20.2-394.3 months), 30 patients had recurrent disease (17 in the FSS group and 13 in the radical surgery group). Multivariate analysis showed no difference in disease-free survival between the FSS and radical surgery groups $(p=0.550)$. In patients who underwent FSS, incomplete staging was significantly associated with the risk of recurrence $(p=0.024)$. Of the 22 patients who wished to conceive, 19 achieved 20 singleton pregnancies. The pregnancy rate was $86.4 \%$ and the live-birth rate was $95 \%$. In 2019, Bergamini et al. [121] presented the results of a study comparing oncologic outcomes of FSS and radical surgery in 239 patients with apparent stage I adult-type granulosa cell tumors of the ovary treated within the MITO group (Multicenter Italian Trials in Ovarian cancer). Among the 78 patients (32.6\%) in the FSS group, $49(62.8 \%)$ underwent unilateral salpingo ovariectomy, $13(16.7 \%)$ cystectomy, and 16 (20.5\%) cystectomy followed by unilateral salpingo-oophorectomy. After a median follow up of 84 months, median disease-free survival was significantly worse in the FSS group (10-year disease-free survival was 50\% in the FSS group vs. $74 \%$ in the radical surgery group, $p=0.006$ ). No significant difference was detected between radical surgery and unilateral salpingo-oophorectomy (10-year disease-free survival $75 \%$ vs. $70 \%$, respectively, $p=0.5$ ). Disease-free survival was significantly worse in the cystectomy group compared with the unilateral salpingo-oophorectomy group (10-year disease-free survival $16 \%$ vs. $70 \%$, respectively, $p=0.001$ ). Patients undergoing cystectomy and subsequent unilateral salpingo-oophorectomy showed a better prognosis, even though significantly worse compared with unilateral salpingo-oophorectomy (10-year disease-free survival $41 \%$ vs. $70 \%, p=0.05$ ). On multivariate analysis, FIGO stage IC and cystectomy had a significant predictive value for worse survival.

In 2019, Gouy et al. published a retrospective pathologic analysis by two expert pathologists of 23 patients with Sertoli-Leydig Cell Tumors (SLCT), and a literature review [112]. The results suggested that FSS should be performed for stage IA disease in children and in women of reproductive age. The difficulty in managing stage IA is determining whether to use an adjuvant treatment. In this population the risk of recurrence was around $7.5 \%$ $(27 / 362)$, irrespective of the type of surgery $(21 / 265-8 \%$ in the FSS group and $6 / 97-6 \%$ in the radical surgery group), but the risk of death after recurrence was as high as $70 \%(19 / 27)$. The same year Xu et al. published a series of seven patients with stage I SLCT of the ovary. Five patients underwent FSS (2IA, 3IC). All the patients were free of disease with a median follow-up of 13.5 months, the longest being 24 months (113). More recently, Durmus et al. (114) published a series of 17 patients with SLCT (13 IA, 2 IC1, and 2 IC2). Eight of the patients underwent total abdominal hysterectomy and bilateral salpingo-oophorectomy, 
seven underwent unilateral salpingo-oophorectomy or oophorectomy, and two underwent cystectomy with or without additional surgical staging procedures. Four patients received adjuvant chemotherapy. All 17 patients were alive and free of disease for 1-287 months after the diagnosis. Median follow-up time was 78 months. Besides the FIGO stage, poor prognosis for SLCT is correlated with poor tumor differentiation and the presence of heterologous elements, as specified in the 2012 European Society for Medical Oncology (ESMO) guidelines [123]. The guidelines recommend that adjuvant chemotherapy be considered for patients with stage I disease (without distinguishing between stages IA and IC) in the presence of these two factors. Schneider et al. showed that the presence of a retiform pattern was also an indicator of poor prognosis [124]. In 2014, the Study Group on Pediatric Rare Tumors described a series of 44 young patients with pediatric SLCT (median age 13 years) and confirmed that the differentiation grade, heterologous elements, and a retiform pattern were prognostic factors [125].

Extreme caution is required to avoid rupture when operating on young patients with a suspected ovarian mass (i.e., oophorectomy should be performed rather than cystectomy) especially if hyperandrogenism is suspected. Young et al. identified rupture as a factor of poor prognosis: the risk of recurrence increased from 30 to $38 \%$ for women with stage IC disease undergoing FSS, and from 14 to $36 \%$ for women undergoing radical surgery [126]. This poor prognosis associated with stage IC disease could be related to the preservation of the ovary (which raises the question of the safety of FSS), to the natural history of SLCT, or to both.

The prognosis of advanced stage disease (i.e., $\geq$ stage II) is poor; advanced stages are associated with a high rate of death. In the literature review by Gouy et al. [112], 14 of the 19 patients with advanced stage disease experienced a recurrence, and 11 died.

In conclusion, for women of reproductive age with stage IA disease, FSS is safe and effective for treating ovarian SLCT. However, more data are needed to define the role of FSS to treat women with stage IC1.

The use of completion surgery after childbearing remains debatable in SCST [127].

\section{Conclusions}

For patients with BOT, FSS gives good fertility results and does not affect survival. It should therefore be offered to young women with a desire to conceive, even if peritoneal implants are discovered at the time of initial surgery. In the case of persistent infertility, ART can be initiated in patients with stage I BOT although the number of stimulation cycles should be limited.

In patients with EOC, FSS should only be considered in adequately staged patients, with stage IA grade 1 (and probably 2, or low-grade in the current classification) serous, mucinous or endometrioid tumors, and with close gynecologic follow-up. FSS could also be offered to patients with stage IC grade 1 (or low-grade) disease.

For women with serous, mucinous or endometrioid high-grade FIGO stage IA or lowgrade FIGO stage IC1 or IC2 EOC tumors, bilateral salpingo-oophorectomy and uterine conservation could be offered to allow pregnancy by egg donation.

Finally, FSS has a large role to play in patients with non-epithelial ovarian cancer, particularly in patients with MGCT.

Author Contributions: Conceptualization, C.U.; Methodology, C.U. and G.C.; validation, C.U.; G.C. and N.C.-B. formal analysis, C.U.; G.C. and N.C.-B.; investigation, C.U. and G.C; resources, C.U. and G.C.; data curation, C.U. and G.C.; writing-original draft preparation, C.U. and G.C.; writingreview and editing, C.U.; G.C. and N.C.-B.; supervision, C.U. All authors have read and agreed to the published version of the manuscript.

Funding: This research received no external funding.

Conflicts of Interest: The authors declare no conflict of interest in relation to this work. 


\section{References}

1. La Rosa, V.L.; Garzon, S.; Gullo, G.; Fichera, M.; Sisti, G.; Gallo, P.; Riemma, G.; Schiattarella, A. Fertility preservation in women affected by gynaecological cancer: The importance of an integrated gynaecological and psychological approach. Ecancermedicalscience 2020, 14, 1035. [CrossRef] [PubMed]

2. Rodriguez-Wallberg, K.A.; Hao, X.; Marklund, A.; Johansen, G.; Borgström, B.; Lundberg, F.E. Hot Topics on Fertility Preservation for Women and Girls-Current Research, Knowledge Gaps, and Future Possibilities. J. Clin. Med. 2021, 10, 1650. [CrossRef]

3. Ray-Coquard, I.; Morice, P.; Lorusso, D.; Prat, J.; Oaknin, A.; Pautier, P.; Colombo, N. Non-epithelial ovarian cancer: ESMO Clinical Practice Guidelines for diagnosis, treatment and follow-up. Ann. Oncol. 2018, 4, iv1-iv18. [CrossRef]

4. Colombo, N.; Sessa, C.; du Bois, A.; Ledermann, J.; McCluggage, W.G.; McNeish, I.; Morice, P.; Pignata, S.; Ray-Coquard, I.; Vergote, I.; et al. ESMO-ESGO consensus conference recommendations on ovarian cancer: Pathology and molecular biology, early and advanced stages, borderline tumours and recurrent disease. Ann. Oncol. 2019, 30, 672-705. [CrossRef]

5. Leary, A.; Petrella, M.C.; Pautier, P.; Duvillard, P.; Uzan, C.; Tazi, Y.; Ledoux, F.; Gouy, S.; Morice, P.; Lhommé, C. Adjuvant platinum-based chemotherapy for borderline serous ovarian tumors with invasive implants. Gynecol. Oncol. 2014, $132,237$. [CrossRef]

6. Trimble, C.L.; Kosary, C.; Trimble, E.L. Long-term survival and patterns of care in women with ovarian tumors of low malignant potential. Gynecol. Oncol. 2002, 86, 34-37. [CrossRef]

7. Daraï, E.; Fauvet, R.; Uzan, C.; Gouy, S.; Duvillard, P.; Morice, P. Fertility and borderline ovarian tumor: A systematic review of conservative management, risk of recurrence and alternative options. Hum. Reprod. Update 2013, 19, 151-166. [CrossRef] [PubMed]

8. Palomba, S.; Zupi, E.; Russo, T.; Falbo, A.; Del Negro, S.; Manguso, F.; Marconi, D.; Tolino, A.; Zullo, F. Comparison of two fertility-sparing approaches for bilateral borderline ovarian tumours: A randomized controlled study. Hum. Reprod. 2007, 22, 578-585. [CrossRef]

9. Palomba, S.; Falbo, A.; Del Negro, S.; Rocca, M.; Russo, T.; Cariati, F.; Annunziata, G.; Tolino, A.; Tagliaferri, P.; Zullo, F. Ultra-conservative fertility-sparing strategy for bilateral borderline ovarian tumours: An 11-year follow-up. Hum. Reprod. 2010, 25, 1966-1972. [CrossRef] [PubMed]

10. Bendifallah, S.; Ballester, M.; Uzan, C.; Fauvet, R.; Morice, P.; Darai, E. Nomogram to predict recurrence in patients with earlyand advanced-stage mucinous and serous borderline ovarian tumors. Am. J. Obstet. Gynecol. 2014, 211, 637.e1-6. [CrossRef] [PubMed]

11. Morice, P.; Uzan, C.; Fauvet, R.; Gouy, S.; Duvillard, P.; Darai, E. Borderline ovarian tumour: Pathological diagnostic dilemma and risk factors for invasive or lethal recurrence. Lancet Oncol. 2012, 13, e103-e115. [CrossRef]

12. Gouy, S.; Maria, S.; Faron, M.; Maulard, A.; Pautier, P.; Leary, A.; Chargari, C.; Genestie, C.; Morice, P. Results After Conservative Surgery of Stage II/III Serous Borderline Ovarian Tumors. Ann. Surg. Oncol. 2021, 28, 3597-3604. [CrossRef]

13. Uzan, C.; Nikpayam, M.; Ribassin-Majed, L.; Gouy, S.; Bendifallah, S.; Cortez, A.; Rey, A.; Duvillard, P.; Darai, E.; Morice, P. Influence of histological subtypes on the risk of an invasive recurrence in a large series of stage I borderline ovarian tumor including 191 conservative treatments. Ann. Oncol. 2014, 25, 1312-1319. [CrossRef] [PubMed]

14. Jia, S.-Z.; Xiang, Y.; Yang, J.-J.; Shi, J.-H.; Jia, C.-W.; Leng, J.-H. Oncofertility outcomes after fertility-sparing treatment of bilateral serous borderline ovarian tumors: Results of a large retrospective study. Hum. Reprod. 2020, 35, 328-339. [CrossRef] [PubMed]

15. du Bois, A.; Ewald-Riegler, N.; de Gregorio, N.; Reuss, A.; Mahner, S.; Fotopoulou, C.; Kommoss, F.; Schmalfeldt, B.; Hilpert, F.; Fehm, T.; et al. Borderline tumours of the ovary: A cohort study of the Arbeitsgmeinschaft Gynäkologische Onkologie (AGO) Study Group. Eur. J. Cancer 2013, 49, 1905-1914. [CrossRef] [PubMed]

16. Boran, N.; Cil, A.P.; Tulunay, G.; Ozturkoglu, E.; Koc, S.; Bulbul, D.; Kose, M.F. Fertility and recurrence results of conservative surgery for borderline ovarian tumors. Gynecol. Oncol. 2005, 97, 845-851. [CrossRef]

17. Fauvet, R.; Poncelet, C.; Boccara, J.; Descamps, P.; Fondrinier, E.; Daraï, E. Fertility after conservative treatment for borderline ovarian tumors: A French multicenter study. Fertil. Steril. 2005, 83, 284-290. [CrossRef]

18. Park, J.-Y.; Kim, D.-Y.; Kim, J.-H.; Kim, Y.-M.; Kim, Y.-T.; Nam, J.-H. Surgical management of borderline ovarian tumors: The role of fertility-sparing surgery. Gynecol. Oncol. 2009, 113, 75-82. [CrossRef]

19. Kanat-Pektas, M.; Ozat, M.; Gungor, T.; Dikici, T.; Yilmaz, B.; Mollamahmutoglu, L. Fertility outcome after conservative surgery for borderline ovarian tumors: A single center experience. Arch. Gynecol. Obstet. 2011, 284, 1253-1258. [CrossRef]

20. Koskas, M.; Uzan, C.; Gouy, S.; Pautier, P.; Lhommé, C.; Haie-Meder, C.; Duvillard, P.; Morice, P. Fertility determinants after conservative surgery for mucinous borderline tumours of the ovary (excluding peritoneal pseudomyxoma). Hum. Reprod. 2011, 26, 808-814. [CrossRef] [PubMed]

21. Song, T.; Choi, C.H.; Kim, H.J.; Lee, W.; Lee, Y.Y.; Kim, T.J.; Lee, J.W.; Bae, D.S.; Kim, B.G. Oncologic and reproductive outcomes in patients with advanced-stage borderline ovarian tumors. Eur. J. Obstet. Gynecol. Reprod. Biol. 2011, 156, 204-208. [CrossRef] [PubMed]

22. Lee, S.Y.; Choi, M.C.; Kwon, B.R.; Jung, S.G.; Park, H.; Joo, W.D.; Lee, C.; Lee, J.H.; Lee, J.M. Oncologic and obstetric outcomes of conservative surgery for borderline ovarian tumors in women of reproductive age. Obstet. Gynecol. Sci. 2017, 60, 289-295. [CrossRef] [PubMed] 
23. Delle Marchette, M.; Ceppi, L.; Andreano, A.; Bonazzi, C.M.; Buda, A.; Grassi, T.; Giuliani, D.; Sina, F.; Lamanna, M.; Bianchi, T.; et al. Oncologic and fertility impact of surgical approach for borderline ovarian tumours treated with fertility sparing surgery. Eur. J. Cancer 2019, 111, 61-68. [CrossRef] [PubMed]

24. Lu, Z.; Li, B.; Gu, C. Outcomes of fertility-sparing surgery for stage II and III serous borderline ovarian tumors. J. Int. Med. Res. 2019, 47, 4895-4903. [CrossRef] [PubMed]

25. Candotti, G.; Peiretti, M.; Mangili, G.; Bergamini, A.; Candiani, M.; Cioffi, R.; Mais, V.; Rabaiotti, E.; Bocciolone, L. What women want: Fertility sparing surgery in Borderline ovarian tumours patients and pregnancy outcome. Eur. J. Surg. Oncol. J. Eur. Soc. Surg. Oncol. Br. Assoc. Surg. Oncol. 2020, 46, 888-892. [CrossRef] [PubMed]

26. Chevrot, A.; Pouget, N.; Bats, A.S.; Huchon, C.; Guyon, F.; Chopin, N.; Rousset-Jablonski, C.; Beurrier, F.; Lambaudie, E.; Provansal, M.; et al. Fertility and prognosis of borderline ovarian tumor after conservative management: Results of the multicentric OPTIBOT study by the GINECO \& TMRG group. Gynecol. Oncol. 2020, 157, 29-35. [PubMed]

27. Plett, H.; Harter, P.; Ataseven, B.; Heitz, F.; Prader, S.; Schneider, S.; Heikaus, S.; Fisseler-Eckhoff, A.; Kommoss, F.; Lax, S.F.; et al. Fertility-sparing surgery and reproductive-outcomes in patients with borderline ovarian tumors. Gynecol. Oncol. 2020, 157, 411-417. [CrossRef] [PubMed]

28. Trillsch, F.; Mahner, S.; Woelber, L.; Vettorazzi, E.; Reuss, A.; Ewald-Riegler, N.; de Gregorio, N.; Fotopoulou, C.; Schmalfeldt, B.; Burges, A.; et al. Age-dependent differences in borderline ovarian tumours (BOT) regarding clinical characteristics and outcome: Results from a sub-analysis of the Arbeitsgemeinschaft Gynaekologische Onkologie (AGO) ROBOT study. Ann. Oncol. 2014, 25, 1320-1327. [CrossRef]

29. Fauvet, R.; Demblocque, E.; Morice, P.; Querleu, D.; Daraï, E. Behavior of serous borderline ovarian tumors with and without micropapillary patterns: Results of a French multicenter study. Ann. Surg. Oncol. 2012, 19, 941-947. [CrossRef]

30. Ouldamer, L.; Bendifallah, S.; Naoura, I.; Body, G.; Uzan, C.; Morice, P.; Ballester, M.; Daraï, E. Nomogram to predict live birth rate after fertility-sparing surgery for borderline ovarian tumours. Hum. Reprod. 2016, 31, 1732-1737. [CrossRef]

31. Jiao, X.; Hu, J.; Zhu, L. Prognostic Factors for Recurrence After Fertility-Preserving Surgery in Patients with Borderline Ovarian Tumors: A Systematic Review and Meta-analysis of Observational Studies. Int. J. Gynecol. Cancer 2017, 27, 1833-1841. [CrossRef]

32. Rizzuto, I.; Behrens, R.F.; Smith, L.A. Risk of ovarian cancer in women treated with ovarian stimulating drugs for infertility. Cochrane Database Syst. Rev. 2013, 8, CD008215. [CrossRef] [PubMed]

33. Basille, C.; Olivennes, F.; Le Calvez, J.; Beron-Gaillard, N.; Meduri, G.; Lhommé, C.; Duvillard, P.; Benard, J.; Morice, P. Impact of gonadotrophins and steroid hormones on tumour cells derived from borderline ovarian tumours. Hum. Reprod. 2006, 21, 3241-3245. [CrossRef] [PubMed]

34. Nijman, H.W.; Burger, C.W.; Baak, J.P.; Schats, R.; Vermorken, J.B.; Kenemans, P. Borderline malignancy of the ovary and controlled hyperstimulation, a report of 2 cases. Eur. J. Cancer 1992, 28, 1971-1973. [CrossRef]

35. Mantzavinos, T.; Kanakas, N.; Genatas, C.; Papadias, K.; Zourlas, P.A. Five years' follow-up in two patients with borderline tumours of the ovary hyperstimulated by gonadotrophin therapy for in-vitro fertilization. Hum. Reprod. 1994, 9, 2032-2033. [CrossRef]

36. Lawal, A.H.; B-Lynch, C. Borderline ovarian cancer, bilateral surgical castration, chemotherapy and a normal delivery after ovum donation and in vitro fertilisation-embryo transfer. Br. J. Obstet. Gynaecol. 1996, 103, 931-932. [CrossRef] [PubMed]

37. Hoffman, J.S.; Laird, L.; Benadiva, C.; Dreiss, R. In vitro fertilization following conservative management of stage 3 serous borderline tumor of the ovary. Gynecol Oncol. 1999, 74, 515-518. [CrossRef]

38. Gallot, D.; Pouly, J.L.; Janny, L.; Mage, G.; Canis, M.; Wattiez, A.; Bruhat, M.A. Successful transfer of frozen-thawed embryos obtained immediately before radical surgery for stage IIIa serous borderline ovarian tumour: Case report. Hum. Reprod. 2000, 15, 2347-2350. [CrossRef]

39. Morris, R.T.; Gershenson, D.M.; Silva, E.G.; Follen, M.; Morris, M.; Wharton, J.T. Outcome and reproductive function after conservative surgery for borderline ovarian tumors. Obstet. Gynecol. 2000, 95, 541-547.

40. Beiner, M.E.; Gotlieb, W.H.; Davidson, B.; Kopolovic, J.; Ben-Baruch, G. Infertility treatment after conservative management of borderline ovarian tumors. Cancer 2001, 92, 320-325. [CrossRef]

41. Attar, E.; Berkman, S.; Topuz, S.; Baysal, B.; Akhan, S.; Chambers, J.T. Evolutive peritoneal disease after conservative management and the use of infertility drugs in a patient with stage IIIC borderline micro-papillary serous carcinoma (MPSC) of the ovary: Case report. Hum. Reprod. 2004, 19, 1472-1475. [CrossRef]

42. Fasouliotis, S.J.; Davis, O.; Schattman, G.; Spandorfer, S.D.; Kligman, I.; Rosenwaks, Z. Safety and efficacy of infertility treatment after conservative management of borderline ovarian tumors: A preliminary report. Fertil. Steril. 2004, 82, 568-572. [CrossRef] [PubMed]

43. Marcickiewicz, J.; Brännström, M. Fertility preserving surgical treatment of borderline ovarian tumour: Long-term consequence for fertility and recurrence. Acta. Obstet. Gynecol. Scand. 2006, 85, 1496-1500. [CrossRef] [PubMed]

44. Fortin, A.; Morice, P.; Thoury, A.; Camatte, S.; Dhainaut, C.; Madelenat, P. Impact of infertility drugs after treatment of borderline ovarian tumors: Results of a retrospective multicenter study. Fertil. Steril. 2007, 87, 591-596. [CrossRef] [PubMed]

45. Park, C.W.; Yang, K.M.; Kim, H.O.; Hong, S.R.; Kim, T.J.; Lim, K.T.; Lee, K.H.; Kang, I.S. Outcomes of controlled ovarian hyperstimulation/in vitro fertilization for infertile patients with borderline ovarian tumor after conservative treatment. J. Korean. Med. Sci. 2007, 22, S134-S138. [CrossRef] [PubMed] 
46. Yinon, Y.; Beiner, M.E.; Gotlieb, W.H.; Korach, Y.; Perri, T.; Ben-Baruch, G. Clinical outcome of cystectomy compared with unilateral salpingo-oophorectomy as fertility-sparing treatment of borderline ovarian tumors. Fertil. Steril. 2007, 88, 479-484. [CrossRef]

47. Porcu, E.; Venturoli, S.; Damiano, G.; Ciotti, P.M.; Notarangelo, L.; Paradisi, R.; Moscarini, M.; Ambrosini, G. Healthy twins delivered after oocyte cryopreservation and bilateral ovariectomy for ovarian cancer. Reprod. Biomed. Online 2008, 17, $265-267$. [CrossRef]

48. Cabenda-Narain, N.E.; Jansen, F.W.; Dieben, S.W.M.; Verburg, H.J.; Gaarenstroom, K.N. Conservatively treated borderline ovarian tumours, followed by IVF treatment: A case series. J. Obstet. Gynaecol. 2011, 31, 327-329. [CrossRef]

49. Childress, K.J.; Patil, N.M.; Muscal, J.A.; Dietrich, J.E.; Venkatramani, R. Borderline Ovarian Tumor in the Pediatric and Adolescent Population: A Case Series and Literature Review. J. Pediatr. Adolesc. Gynecol. 2018, 31, 48-54. [CrossRef]

50. Nasioudis, D.; Alevizakos, M.; Holcomb, K.; Witkin, S.S. Malignant and borderline epithelial ovarian tumors in the pediatric and adolescent population. Maturitas 2017, 96, 45-50. [CrossRef]

51. Zanetta, G.; Chiari, S.; Rota, S.; Bratina, G.; Maneo, A.; Torri, V.; Mangioni, C. Conservative surgery for stage I ovarian carcinoma in women of childbearing age. Br. J. Obstet. Gynaecol. 1997, 104, 1030-1035. [CrossRef] [PubMed]

52. Schilder, J.M.; Thompson, A.M.; DePriest, P.D.; Ueland, F.R.; Cibull, M.L.; Kryscio, R.J.; Modesitt, S.C.; Lu, K.H.; Geisler, J.P.; Higgins, R.V.; et al. Outcome of reproductive age women with stage IA or IC invasive epithelial ovarian cancer treated with fertility-sparing therapy. Gynecol. Oncol. 2002, 87, 1-7. [CrossRef]

53. Morice, P.; Leblanc, E.; Rey, A.; Baron, M.; Querleu, D.; Blanchot, J.; Duvillard, P.; Lhommé, C.; Castaigne, D.; Classe, J.M.; et al. Conservative treatment in epithelial ovarian cancer: Results of a multicentre study of the GCCLCC (Groupe des Chirurgiens de Centre de Lutte Contre le Cancer) and SFOG (Société Francaise d'Oncologie Gynécologique). Hum. Reprod. 2005, 20, 1379-1385. [CrossRef] [PubMed]

54. Borgfeldt, C.; Iosif, C.; Måsbäck, A. Fertility-sparing surgery and outcome in fertile women with ovarian borderline tumors and epithelial invasive ovarian cancer. Eur. J. Obstet. Gynecol. Reprod. Biol. 2007, 134, 110-114. [CrossRef] [PubMed]

55. Park, J.-Y.; Kim, D.-Y.; Suh, D.-S.; Kim, J.-H.; Kim, Y.-M.; Kim, Y.-T.; Nam, J.H. Outcomes of fertility-sparing surgery for invasive epithelial ovarian cancer: Oncologic safety and reproductive outcomes. Gynecol. Oncol. 2008, 110, 345-353. [CrossRef] [PubMed]

56. Anchezar, J.P.; Sardi, J.; Soderini, A. Long-term follow-up results of fertility sparing surgery in patients with epithelial ovarian cancer. J. Surg. Oncol. 2009, 100, 55-58. [CrossRef]

57. Schlaerth, A.C.; Chi, D.S.; Poynor, E.A.; Barakat, R.R.; Brown, C.L. Long-term survival after fertility-sparing surgery for epithelial ovarian cancer. Int. J. Gynecol. Cancer 2009, 19, 1199-1204. [CrossRef]

58. Kwon, Y.-S.; Hahn, H.-S.; Kim, T.-J.; Lee, I.-H.; Lim, K.-T.; Lee, K.-H.; Shim, J.U.; Mok, J.E. Fertility preservation in patients with early epithelial ovarian cancer. J. Gynecol. Oncol. 2009, 20, 44-47. [CrossRef]

59. Wright, J.D.; Shah, M.; Mathew, L.; Burke, W.M.; Culhane, J.; Goldman, N.; Schiff, P.B.; Herzog, T.J. Fertility preservation in young women with epithelial ovarian cancer. Cancer 2009, 115, 4118-4126. [CrossRef]

60. Satoh, T.; Hatae, M.; Watanabe, Y.; Yaegashi, N.; Ishiko, O.; Kodama, S.; Yamaguchi, S.; Ochiai, K.; Takano, M.; Yokota, H.; et al. Outcomes of fertility-sparing surgery for stage I epithelial ovarian cancer: A proposal for patient selection. J. Clin. Oncol. 2010, 28, 1727-1732. [CrossRef]

61. Kajiyama, H.; Shibata, K.; Suzuki, S.; Ino, K.; Nawa, A.; Kawai, M.; Nagasaka, T.; Kikkawa, F. Fertility-sparing surgery in young women with invasive epithelial ovarian cancer. Eur. J. Surg. Oncol. J. Eur. Soc. Surg. Oncol. Br. Assoc. Surg. Oncol. 2010, 36, 404-408. [CrossRef] [PubMed]

62. Hu, J.; Zhu, L.R.; Liang, Z.Q.; Meng, Y.G.; Guo, H.Y.; Qu, P.P.; Ma, C.L.; Xu, C.J.; Yuan, B.B. Clinical outcomes of fertility-sparing treatments in young patients with epithelial ovarian carcinoma. J. Zhejiang Univ. Sci. B 2011, 12, 787-795. [CrossRef] [PubMed]

63. Kajiyama, H.; Shibata, K.; Mizuno, M.; Umezu, T.; Suzuki, S.; Nawa, A.; Kawai, M.; Nagasaka, T.; Kikkawa, F. Long-term survival of young women receiving fertility-sparing surgery for ovarian cancer in comparison with those undergoing radical surgery. $\mathrm{Br}$. J. Cancer 2011, 105, 1288-1294. [CrossRef] [PubMed]

64. Cheng, X.; Cheng, B.; Wan, X.; Lu, W.; Xie, X. Outcomes of conservative surgery in early epithelial ovarian carcinoma. Eur. J. Gynaecol. Oncol. 2012, 33, 93-95. [CrossRef] [PubMed]

65. Fruscio, R.; Corso, S.; Ceppi, L.; Garavaglia, D.; Garbi, A.; Floriani, I.; Franchi, D.; Cantù, M.G.; Bonazzi, C.M.; Milani, R.; et al. Conservative management of early-stage epithelial ovarian cancer: Results of a large retrospective series. Ann. Oncol. 2013, 24, 138-144. [CrossRef] [PubMed]

66. Fruscio, R.; Ceppi, L.; Corso, S.; Galli, F.; Dell'Anna, T.; Dell'Orto, F.; Giuliani, D.; Garbi, A.; Chiari, S.; Mangioni, C.; et al. Long-term results of fertility-sparing treatment compared with standard radical surgery for early-stage epithelial ovarian cancer. Br. J. Cancer 2016, 115, 641-648. [CrossRef] [PubMed]

67. Kashima, K.; Yahata, T.; Fujita, K.; Tanaka, K. Outcomes of fertility-sparing surgery for women of reproductive age with FIGO stage IC epithelial ovarian cancer. Int. J. Gynaecol. Obstet. Off. Organ. Int. Fed. Gynaecol. Obstet. 2013, 121, 53-55. [CrossRef]

68. Kajiyama, H.; Mizuno, M.; Shibata, K.; Yamamoto, E.; Kawai, M.; Nagasaka, T.; Kikkawa, F. Recurrence-predicting prognostic factors for patients with early-stage epithelial ovarian cancer undergoing fertility-sparing surgery: A multi-institutional study. Eur. J. Obstet. Gynecol. Reprod. Biol. 2014, 175, 97-102. [CrossRef]

69. Lee, J.-Y.; Jo, Y.R.; Kim, T.H.; Kim, H.S.; Kim, M.A.; Kim, J.W.; Park, N.H.; Song, Y.-S. Safety of fertility-sparing surgery in primary mucinous carcinoma of the ovary. Cancer Res. Treat. 2015, 47, 290-297. [CrossRef] 
70. Ditto, A.; Martinelli, F.; Bogani, G.; Lorusso, D.; Carcangiu, M.; Chiappa, V.; Reato, C.; Donfrancesco, C.; De Carrillo, K.J.A.; Raspagliesi, F. Long-term safety of fertility sparing surgery in early stage ovarian cancer: Comparison to standard radical surgical procedures. Gynecol. Oncol. 2015, 138, 78-82. [CrossRef]

71. Bentivegna, E.; Gouy, S.; Maulard, A.; Pautier, P.; Leary, A.; Colombo, N.; Morice, P. Fertility-sparing surgery in epithelial ovarian cancer: A systematic review of oncological issues. Ann. Oncol. 2016, 27, 1994-2004. [CrossRef]

72. Gouy, S.; Saidani, M.; Maulard, A.; Bach-Hamba, S.; Bentivegna, E.; Leary, A.; Pautier, P.; Devouassoux-Shisheboran, M.; Genestie, C.; Morice, P. Results of Fertility-Sparing Surgery for Expansile and Infiltrative Mucinous Ovarian Cancers. Oncologist 2018, 23, 324-327. [CrossRef]

73. Jiang, X.; Yang, J.; Yu, M.; Xie, W.; Cao, D.; Wu, M.; Pan, L.; Huang, H.; You, Y.; Shen, K. Oncofertility in patients with stage I epithelial ovarian cancer: Fertility-sparing surgery in young women of reproductive age. World J. Surg. Oncol. 2017, 15, 154. [CrossRef]

74. Melamed, A.; Rizzo, A.E.; Nitecki, R.; Gockley, A.A.; Bregar, A.J.; Schorge, J.O.; Del Carmen, M.G.; Rauh-Hain, J.A. All-Cause Mortality After Fertility-Sparing Surgery for Stage I Epithelial Ovarian Cancer. Obstet. Gynecol. 2017, 130, 71-79. [CrossRef] [PubMed]

75. Ratanasrithong, P.; Benjapibal, M. Pregnancy Outcomes after Conservative Surgery for Early-Stage Ovarian Neoplasms. Asian Pac. J. Cancer Prev. 2017, 18, 2083-2087. [PubMed]

76. Hanatani, M.; Yoshikawa, N.; Yoshida, K.; Tamauchi, S.; Ikeda, Y.; Nishino, K.; Niimi, K.; Suzuki, S.; Kawai, M.; Kajiyama, H.; et al. Impact of age on clinicopathological features and survival of epithelial ovarian neoplasms in reproductive age. Int. J. Clin. Oncol. 2020, 25, 187-194. [CrossRef] [PubMed]

77. Kajiyama, H.; Suzuki, S.; Niimi, K.; Tamauchi, S.; Kawai, M.; Nagasaka, T.; Shibata, K.; Kikkawa, F. Oncologic and reproductive outcomes of cystectomy as a fertility-sparing treatment for early-stage epithelial ovarian cancer. Int. J. Clin. Oncol. 2019, 24, 857-862. [CrossRef]

78. Bogani, G.; Ditto, A.; Pinelli, C.; Lopez, S.; Chiappa, V.; Raspagliesi, F. Ten-year follow-up study of long-term outcomes after conservative surgery for early-stage ovarian cancer. Int. J. Gynaecol. Obstet. Off. Organ. Int. Fed. Gynaecol. Obstet. 2020, 150, 169-176. [CrossRef]

79. Liu, D.; Cai, J.; Gao, A.; Wang, Z.; Cai, L. Fertility sparing surgery vs radical surgery for epithelial ovarian cancer: A meta-analysis of overall survival and disease-free survival. BMC Cancer 2020, 20, 320. [CrossRef]

80. Watanabe, T.; Soeda, S.; Nishiyama, H.; Kiko, Y.; Tokunaga, H.; Shigeta, S.; Yaegashi, N.; Yamada, H.; Ohta, T.; Nagase, S.; et al. Clinical and reproductive outcomes of fertility-sparing surgery in stage I epithelial ovarian cancer. Mol. Clin. Oncol. 2020, 12, 44-50. [CrossRef]

81. Zhang, Y.; Li, C.; Luo, S.; Su, Y.; Gang, X.; Chu, P.; Zhang, J.; Wu, H.; Liu, G. Retrospective Study of the Epidemiology, Pathology, and Therapeutic Management in Patients with Mucinous Ovarian Tumors. Technol. Cancer. Res. Treat. 2020, 19, 1533033820946423. [CrossRef] [PubMed]

82. Colombo, N.; Chiari, S.; Maggioni, A.; Bocciolone, L.; Torri, V.; Mangioni, C. Controversial issues in the management of early epithelial ovarian cancer: Conservative surgery and role of adjuvant therapy. Gynecol. Oncol. 1994, 55, S47-S51. [CrossRef] [PubMed]

83. DiSaia, P.J. Conservative management of the patient with early gynecologic cancer. CA Cancer J. Clin. 1989, 39, 135-154. [CrossRef] [PubMed]

84. Bentivegna, E.; Fruscio, R.; Roussin, S.; Ceppi, L.; Satoh, T.; Kajiyama, H.; Uzan, C.; Colombo, N.; Gouy, S.; Morice, P. Long-term follow-up of patients with an isolated ovarian recurrence after conservative treatment of epithelial ovarian cancer: Review of the results of an international multicenter study comprising 545 patients. Fertil. Steril. 2015, 104, 1319-1324. [CrossRef] [PubMed]

85. Kajiyama, H.; Shibata, K.; Suzuki, S.; Ino, K.; Yamamoto, E.; Mizuno, K.; Sakakibara, K.; Matsuzawa, K.; Takeda, A.; Kinoshita, Y.; et al. Is there any possibility of fertility-sparing surgery in patients with clear-cell carcinoma of the ovary? Gynecol. Oncol. 2008, 111, 523-526. [CrossRef]

86. Park, J.-Y.; Suh, D.-S.; Kim, J.-H.; Kim, Y.-M.; Kim, Y.-T.; Nam, J.-H. Outcomes of fertility-sparing surgery among young women with FIGO stage I clear cell carcinoma of the ovary. Int. J. Gynaecol. Obstet. Off. Organ. Int. Fed. Gynaecol. Obstet. 2016, 134, 49-52. [CrossRef]

87. Petrillo, M.; Legge, F.; Ferrandina, G.; Monterisi, A.; Pedone Anchora, L.; Scambia, G. Fertility-sparing surgery in ovarian cancer extended beyond the ovaries: A case report and review of the literature. Gynecol. Obstet. Investig. 2014, 77, 1-5. [CrossRef] [PubMed]

88. Peccatori, F.; Bonazzi, C.; Chiari, S.; Landoni, F.; Colombo, N.; Mangioni, C. Surgical management of malignant ovarian germ-cell tumors: 10 years' experience of 129 patients. Obstet. Gynecol. 1995, 86, 367-372. [CrossRef]

89. Mitchell, P.L.; Al-Nasiri, N.; A’Hern, R.; Fisher, C.; Horwich, A.; Pinkerton, C.R.; Shepherd, J.H.; Gallagher, C.; Slevin, M.; Harper, P.; et al. Treatment of nondysgerminomatous ovarian germ cell tumors: An analysis of 69 cases. Cancer 1999, 85, 2232-2244. [CrossRef]

90. Brewer, M.; Gershenson, D.M.; Herzog, C.E.; Mitchell, M.F.; Silva, E.G.; Wharton, J.T. Outcome and reproductive function after chemotherapy for ovarian dysgerminoma. J. Clin. Oncol. 1999, 17, 2670-2675. [CrossRef]

91. Perrin, L.C.; Low, J.; Nicklin, J.L.; Ward, B.G.; Crandon, A.J. Fertility and ovarian function after conservative surgery for germ cell tumours of the ovary. Aust. N. Z. J. Obstet. Gynaecol. 1999, 39, 243-245. 
92. Tewari, K.; Cappuccini, F.; Disaia, P.J.; Berman, M.L.; Manetta, A.; Kohler, M.F. Malignant germ cell tumors of the ovary. Obstet Gynecol. 2000, 95, 128-133.

93. Low, J.J.; Perrin, L.C.; Crandon, A.J.; Hacker, N.F. Conservative surgery to preserve ovarian function in patients with malignant ovarian germ cell tumors. A review of 74 cases. Cancer 2000, 89, 391-398. [CrossRef]

94. Zanetta, G.; Bonazzi, C.; Cantù, M.; Binidagger, S.; Locatelli, A.; Bratina, G.; Mangioni, C. Survival and reproductive function after treatment of malignant germ cell ovarian tumors. J. Clin. Oncol. 2001, 19, 1015-1020. [CrossRef]

95. Tangir, J.; Zelterman, D.; Ma, W.; Schwartz, P.E. Reproductive function after conservative surgery and chemotherapy for malignant germ cell tumors of the ovary. Obstet. Gynecol. 2003, 101, 251-257. [CrossRef] [PubMed]

96. Zanagnolo, V.; Sartori, E.; Galleri, G.; Pasinetti, B.; Bianchi, U. Clinical review of 55 cases of malignant ovarian germ cell tumors. Eur. J. Gynaecol. Oncol. 2004, 25, 315-320. [PubMed]

97. Boran, N.; Tulunay, G.; Caliskan, E.; Köse, M.F.; Haberal, A. Pregnancy outcomes and menstrual function after fertility sparing surgery for pure ovarian dysgerminomas. Arch. Gynecol. Obstet. 2005, 271, 104-108. [CrossRef] [PubMed]

98. Ayhan, A.; Celik, H.; Taskiran, C.; Bozdag, G.; Aksu, T. Oncologic and reproductive outcome after fertility-saving surgery in ovarian cancer. Eur. J. Gynaecol. Oncol. 2003, 24, 223-232. [PubMed]

99. Kang, H.; Kim, T.-J.; Kim, W.Y.; Choi, C.H.; Lee, J.-W.; Kim, B.-G.; Bae, D.-S. Outcome and reproductive function after cumulative high-dose combination chemotherapy with bleomycin, etoposide and cisplatin (BEP) for patients with ovarian endodermal sinus tumor. Gynecol. Oncol. 2008, 111, 106-110. [CrossRef]

100. de La Motte Rouge, T.; Pautier, P.; Duvillard, P.; Rey, A.; Morice, P.; Haie-Meder, C.; Kerbrat, P.; Culine, S.; Troalen, F.; Lhommé, C. Survival and reproductive function of 52 women treated with surgery and bleomycin, etoposide, cisplatin (BEP) chemotherapy for ovarian yolk sac tumor. Ann. Oncol. 2008, 19, 1435-1441. [CrossRef] [PubMed]

101. Ertas, I.E.; Taskin, S.; Goklu, R.; Bilgin, M.; Goc, G.; Yildirim, Y.; Ortaç, F.; Taşkın, S. Long-term oncological and reproductive outcomes of fertility-sparing cytoreductive surgery in females aged 25 years and younger with malignant ovarian germ cell tumors. J. Obstet. Gynaecol. Res. 2014, 40, 797-805. [CrossRef]

102. Satoh, T.; Aoki, Y.; Kasamatsu, T.; Ochiai, K.; Takano, M.; Watanabe, Y.; Kikkawa, F.; Takeshima, N.; Hatae, M.; Yokota, H.; et al. Administration of standard-dose BEP regimen (bleomycin+etoposide+cisplatin) is essential for treatment of ovarian yolk sac tumour. Eur. J. Cancer 2015, 51, 340-351. [CrossRef]

103. Yang, Z.; Liu, Z.; Wei, R.; Li, L. An Analysis of Prognostic Factors in Patients with Ovarian Malignant Germ Cell Tumors Who Are Treated with Fertility-Preserving Surgery. Gynecol. Obstet. Investig. 2016, 81, 1-9. [CrossRef]

104. Ghalleb, M.; Bouzaiene, H.; Slim, S.; Hadiji, A.; Hechiche, M.; Hassouna, J.B.; Rahal, K. Fertility-sparing surgery in advanced stage malignant ovarian germ cell tumor: A case report. J. Med. Case. Reports 2017, 11, 350. [CrossRef]

105. Park, J.-Y.; Kim, D.-Y.; Suh, D.-S.; Kim, J.-H.; Kim, Y.-M.; Kim, Y.-T.; Nam, J.-H. Analysis of outcomes and prognostic factors after fertility-sparing surgery in malignant ovarian germ cell tumors. Gynecol. Oncol. 2017, 145, 513-518. [CrossRef] [PubMed]

106. de Bénazé, G.D.; Pacquement, H.; Faure-Conter, C.; Patte, C.; Orbach, D.; Corradini, N.; Berger, C.; Sudour-Bonnange, H.; Vérité, C.; Martelli, H.; et al. Paediatric dysgerminoma: Results of three consecutive French germ cell tumours clinical studies (TGM-85/90/95) with late effects study. Eur. J. Cancer 2018, 91, 30-37. [CrossRef] [PubMed]

107. Lakshmanan, M.; Gupta, S.; Kumar, V.; Akhtar, N.; Chaturvedi, A.; Misra, S.; Jain, K.; Garg, S. Germ Cell Tumor Ovary: An Institutional Experience of Treatment and Survival Outcomes. Indian J. Surg. Oncol. 2018, 9, 215-219. [CrossRef]

108. Tamauchi, S.; Kajiyama, H.; Yoshihara, M.; Ikeda, Y.; Yoshikawa, N.; Nishino, K.; Utsumi, F.; Niimi, K.; Suzuki, S.; Kikkawa, F. Reproductive outcomes of 105 malignant ovarian germ cell tumor survivors: A multicenter study. Am. J. Obstet. Gynecol. 2018, 219, 385.e1-385.e7. [CrossRef]

109. Dellino, M.; Silvestris, E.; Loizzi, V.; Paradiso, A.; Loiacono, R.; Minoia, C.; Daniele, A.; Cormio, G. Germinal ovarian tumors in reproductive age women: Fertility-sparing and outcome. Medicine 2020, 99, e22146. [CrossRef] [PubMed]

110. Turkmen, O.; Karalok, A.; Basaran, D.; Kimyon, G.C.; Tasci, T.; Ureyen, I.; Tulunay, G.; Turan, T. Fertility-Sparing Surgery Should Be the Standard Treatment in Patients with Malignant Ovarian Germ Cell Tumors. J. Adolesc. Young Adult Oncol. 2017, 6, 270-276. [CrossRef] [PubMed]

111. Sahoo, T.K.; Kar, T.; Kar, A.; Panda, S. Poorly Differentiated Sertoli-Leydig Cell Tumour of Ovary with Heterologous Elements. J. Clin. Diagn. Res. 2017, 11, XD01-XD02. [CrossRef]

112. Gouy, S.; Arfi, A.; Maulard, A.; Pautier, P.; Bentivegna, E.; Leary, A.; Chargari, C.; Genestie, C.; Morice, P. Results from a Monocentric Long-Term Analysis of 23 Patients with Ovarian Sertoli-Leydig Cell Tumors. Oncologist 2019, 24, 702-709. [CrossRef]

113. Xu, Q.; Zou, Y.; Zhang, X.F. Sertoli-Leydig cell tumors of ovary: A case series. Medicine 2018, 97, e12865. [CrossRef] [PubMed]

114. Durmuş, Y.; Kılıç, Ç.; Çakır, C.; Yüksel, D.; Boran, N.; Karalök, A.; Boyraz, G.; Turan, A.T. Sertoli-Leydig cell tumor of the ovary: Analysis of a single institution database and review of the literature. J. Obstet. Gynaecol. Res. 2019, 45, 1311-1318. [CrossRef]

115. Seidler, S.J.; Huber, A.; Nef, J.; Huber, D.E. Sertoli-Leydig Cell Ovarian Tumors: Is Fertility or Endocrine-Sparing Surgery an Option upon Relapse? Case Rep. Oncol. 2020, 13, 935-940. [CrossRef]

116. Guo, Y.; Wang, J.; Li, Y.; Wang, Y. Ovarian Sertoli-Leydig cell tumors: An analysis of 13 cases. Arch. Gynecol. Obstet. 2020, 302, 203-208. [CrossRef]

117. Zhang, M.; Cheung, M.K.; Shin, J.Y.; Kapp, D.S.; Husain, A.; Teng, N.N.; Berek, J.S.; Osann, K.; Chan, J.K. Prognostic factors responsible for survival in sex cord stromal tumors of the ovary-an analysis of 376 women. Gynecol. Oncol. 2007, 104, 396-400. [CrossRef] [PubMed] 
118. Iavazzo, C.; Gkegkes, I.D.; Vrachnis, N. Fertility sparing management and pregnancy in patients with granulosa cell tumour of the ovaries. J. Obstet. Gynaecol. 2015, 35, 331-335. [CrossRef] [PubMed]

119. Rinne, N.; Farthing, A.; Borley, J. Fertility sparing surgery in advanced and recurrent granulosa cell tumours of the ovary. J. Obstet. Gynaecol. 2018, 38, 143-145. [CrossRef] [PubMed]

120. Wang, D.; Cao, D.; Jia, C.; Huang, H.; Yang, J.; Wu, M.; Pan, L.; Shen, K.; Xiang, Y. Analysis of oncologic and reproductive outcomes after fertility-sparing surgery in apparent stage I adult ovarian granulosa cell tumors. Gynecol. Oncol. 2018, 151, 275-281. [CrossRef]

121. Bergamini, A.; Cormio, G.; Ferrandina, G.; Lorusso, D.; Giorda, G.; Scarfone, G.; Bocciolone, L.; Raspagliesi, F.; Tateo, S.; Cassani, C.; et al. Conservative surgery in stage I adult type granulosa cells tumors of the ovary: Results from the MITO-9 study. Gynecol. Oncol. 2019, 154, 323-327. [CrossRef]

122. Makhija, A.; Patel, B.M.; Kenkre, M.A.; Desai, A.D.; Patel, S.M.; Mankad, M.H.; Parekh, C.D. Retrospective Analysis of 32 Cases of Ovarian Granulosa Cell Tumours. J. Obstet. Gynaecol. India 2020, 70, 50-56. [CrossRef]

123. Colombo, N.; Peiretti, M.; Garbi, A.; Carinelli, S.; Marini, C.; Sessa, C.; ESMO Guidelines Working Group. Non-epithelial ovarian cancer: ESMO Clinical Practice Guidelines for diagnosis, treatment and follow-up. Ann. Oncol. 2012, 23 (Suppl. 7), vii20-vii26. [CrossRef]

124. Schneider, D.T.; Orbach, D.; Cecchetto, G.; Stachowicz-Stencel, T.; Brummel, B.; Brecht, I.B.; Bisogno, G.; Ferrari, A.; Reguerre, Y.; Godzinski, J.; et al. Ovarian Sertoli Leydig cell tumours in children and adolescents: An analysis of the European Cooperative Study Group on Pediatric Rare Tumors (EXPeRT). Eur. J. Cancer 2015, 51, 543-550. [CrossRef]

125. Zhang, H.-Y.; Zhu, J.-E.; Huang, W.; Zhu, J. Clinicopathologic features of ovarian Sertoli-Leydig cell tumors. Int. J. Clin. Exp. Pathol. 2014, 7, 6956-6964. [PubMed]

126. Young, R.H.; Scully, R.E. Ovarian Sertoli-Leydig cell tumors. A clinicopathological analysis of 207 cases. Am. J. Surg. Pathol. 1985, 9, 543-569. [CrossRef] [PubMed]

127. Schumer, S.T.; Cannistra, S.A. Granulosa cell tumor of the ovary. J. Clin. Oncol. 2003, 21, 1180-1189. [CrossRef] [PubMed] 